\title{
FLOODS OF JULY 12, 1972, MARCH 19, 1979, AND JUNE 15, 1991, IN THE TURKEY RIVER BASIN, NORTHEAST IOWA
}

By David A. Eash and Barbar ? A. Koppensteiner

\section{U.S. GEOLOGICAL SURVEY}

Open-File Report 96-560

Prepared in cooperation with the

IOWA HIGHWAY RESEARCH BOARD and the PROJECT DEVELOPMENT DIVISION of the IOWA DEPARTMENT OF TRANSPORTATION (IOWA DOT Research Project HR-140) 


\section{U.S. DEPARTMENT OF THE INTERIOR BRUCE BABBITT, Secretary}

U.S. GEOLOGICAL SURVEY GORDON P. EATON, Director

For additional information write to:

District Chief U.S. Geological Survey Room 269, Federal Building 400 South Clinton Street lowa City, lowa 52244
Copies of this report can be purchased from:

\author{
U.S. Geological Survey \\ Branch of Information Services \\ Box 25286, Denver Federal Center \\ Denver, Colorado 80225-0286
}




\section{CONTENTS}

Abstract

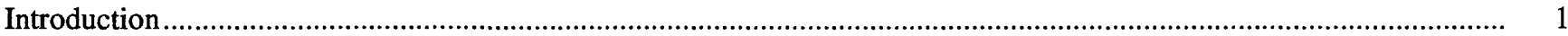

Purpose and scope

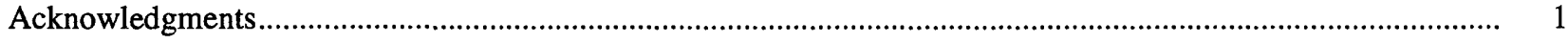

Study area

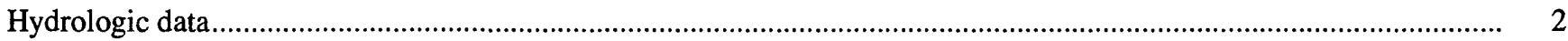

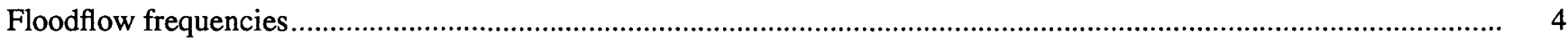

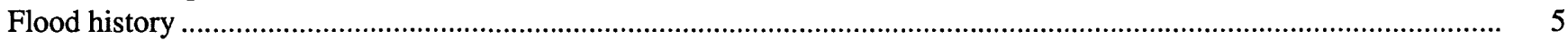

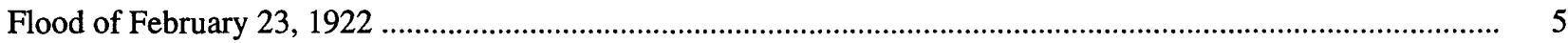

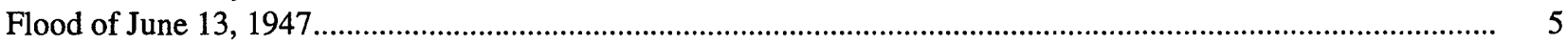

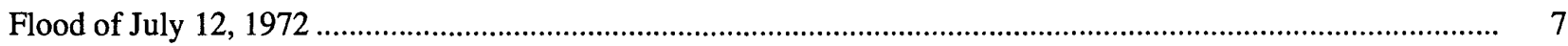

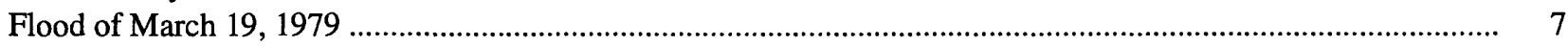

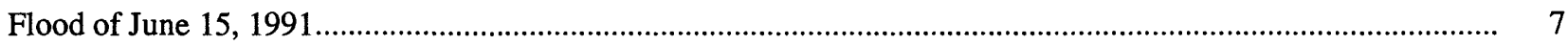

Flood profile

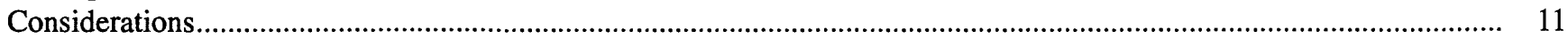

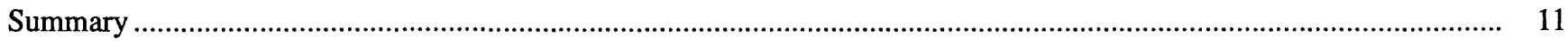

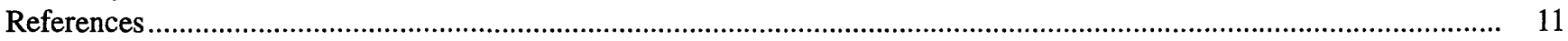

Appendix A. Peak stages and discharges for streamflow-gaging stations in the Turkey River Basin,

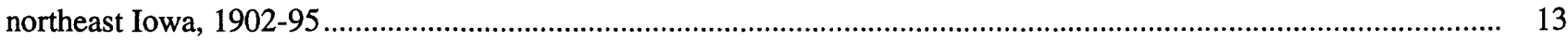

Appendix B. Water-surface-elevation profiles for the Turkey River Basin, northeast Iowa ............................................ 33

Appendix C. Temporary bench marks and reference points in the Turkey River Basin, northeast Iowa.......................... 49

\section{FIGURES}

1. Map of the Turkey River Basin showing location of bridge sites used in July 12, 1972, March 19, 1979, and

June 15, 1991, flood profiles and U.S. Geological Survey streamflow-gaging stations ...

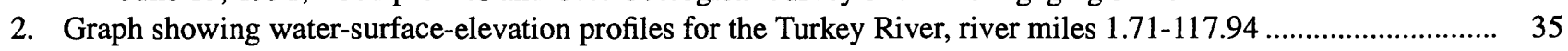

3. Graphs showing water-surface-elevation profiles for the Turkey River,:

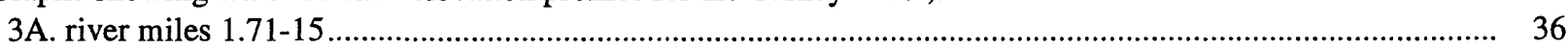

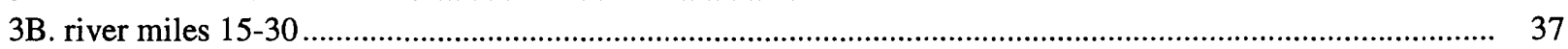

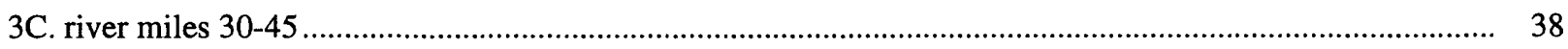

3D. river miles 45-60

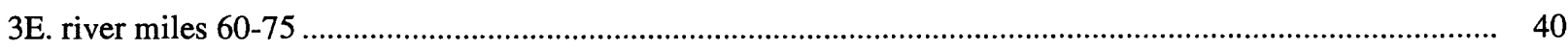

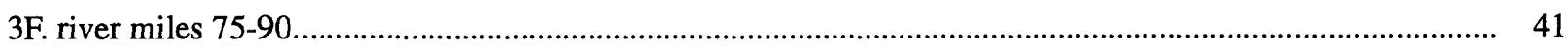

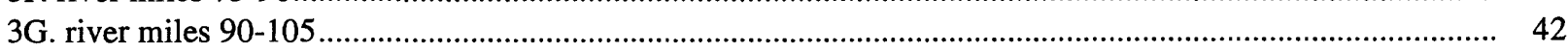

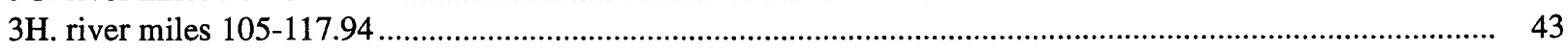

4. Graph showing water-surface-elevation profiles for the Volga River, river miles 0.42-27.68 ............................ 44

5. Graphs showing water-surface-elevation profiles for the Volga River,:

5B. river miles 15-27.68

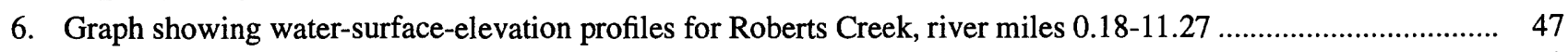

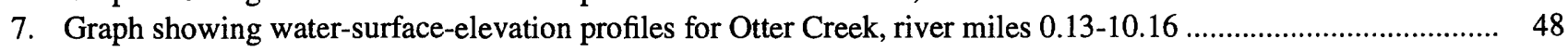

\section{TABLES}

1. Floodflow frequencies for streamflow-gaging stations in the Turkey River Basin .............................................. 6

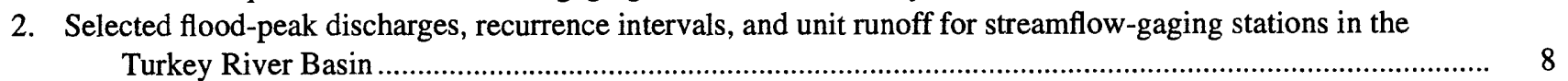




\begin{tabular}{|c|c|c|}
\hline Multiply & By & To obtain \\
\hline inch (in.) & 25.4 & millimeter \\
\hline foot $(\mathrm{ft})$ & 0.3048 & meter \\
\hline mile (mi) & 1.609 & kilometer \\
\hline square mile $\left(\mathrm{mi}^{2}\right)$ & 2.590 & square kilometer \\
\hline cubic foot per second $\left(\mathrm{ft}^{3} / \mathrm{s}\right)$ & 0.02832 & cubic meter per second \\
\hline cubic foot per second per & 0.01093 & cubic meter per second \\
\hline square mile $\left[\left(\mathrm{ft}^{3} / \mathrm{s}\right) / \mathrm{mi}^{2}\right]$ & & per square kilometer \\
\hline ton per acre & 2.242 & megagram per square hectometer \\
\hline
\end{tabular}

Sea Level: In this report, "sea level" refers to the National Geodetic Vertical Datum of 1929--a geodetic datum derived from a general adjustment of the first-order level nets of the United States and Canada, formerly called Sea Level Datum of 1929. 


\title{
Floods of July 12, 1972, March 19, 1979, and June 15, 1991, in the Turkey River Basin, Northeast lowa
}

\author{
By David A. Eash and Barbara A. Koppensteiner
}

\section{ABSTRACT}

Water-surface-elevation profiles and peak discharges for the floods of July 12, 1972, March 19, 1979, and June 15, 1991, in the Turkey River Basin, northeast Iowa, are presented in this report. The profiles illustrate the 1979 and 1991 floods along the Turkey River in Fayette and Clayton Counties and along the Volga River in Clayton County; the 1991 flood along Roberts Creek in Clayton County and along Otter Creek in Fayette County; and the 1972 flood along the Turkey River in Winneshiek and Fayette Counties. Watersurface elevations for the flood of March 19, 1979, were collected by the Iowa Natural Resources Council. The June 15, 1991, flood on the Turkey River at Garber (station number 05412500) is the largest known flood-peak discharge at the streamflow-gaging station for the period 1902-95. The peak discharge for June 15, 1991, of 49,900 cubic feet per second was 1.4 times larger than the 100 -year recurrence-interval discharge. The report provides information on flood stages and discharges and floodflow frequencies for streamflow-gaging stations in the Turkey River Basin using flood information collected during 1902-95. Information on temporary bench marks and reference points established in the Turkey River Basin during 1981, 1992, and 1996 also is included in the report. A flood history describes rainfall conditions for floods that occurred during 1922, 1947, 1972, 1979, and 1991.

\section{INTRODUCTION}

Evaluation of flood hazards and the planning, design, and operation of various structures on flood plains require information about floods. Flood reports supply specific information for selected floods and are used by planners and engineers to evaluate the magnitude and frequency of floods in a river basin.

\section{Purpose and Scope}

This report presents water-surface-elevation profiles for the floods of July 12, 1972, March 19, 1979, and June 15, 1991, in the Turkey River Basin in northeast Iowa. Profiles for the flood of March 19, 1979, use flood elevations collected by the Iowa Natural Resources Council (1980, p. 12) and are presented in this report for comparative purposes. The report provides information on flood stages and discharges, and floodflow frequencies for streamflow-gaging stations in the Turkey River Basin using flood information collected during 1902-95. Information on temporary bench marks and reference points established in the Turkey River Basin during 1981, 1992, and 1996 also is included in the report. A flood history briefly describes rainfall conditions for floods that occurred during 1922, 1947, 1972, 1979, and 1991.

\section{Acknowledgments}

This report was prepared by the U.S. Geological Survey (USGS) in cooperation with the Iowa Highway Research Board and the Project Development Division of the Iowa Department of Transportation. Various Federal, State, and local agencies cooperated in the collection of streamflow records used in this report, the acknowledgment of which is contained in the annual water-data reports of the USGS (U.S. Geological Survey, 1915-96). The authors express their gratitude to the following: Iowa Department of Natural Resources for the use of the water-surface elevations listed in the report "Turkey/Volga River Flood of March 19, 1979" (Iowa Natural Resources Council, 1980); Doug Schindel, Rust Environment and Infrastructure, for providing correlation profiles from which supplemental surface-water elevations were obtained for the flood of June 15, 1991, and low water December 1, 1994; 
Robert W. Baebenroth, James J. Cerveny, Robert D. Goodrich, Maynard Kubicek, Von E. Miller, Bryan D. Schaap, Debra A. Sneck-Fahrer, Dennis A. Steil, Vincent C. Walczyk, and James J. Wellman for collecting the field data for the 1991 flood and surveying level-lines to establish sea-level elevations for the temporary bench marks and reference points; and Trevor L. Birkenholtz for preparing the maps for this report.

\section{STUDY AREA}

The Turkey River Basin is located in northeast Iowa, includes parts of eight counties, and drains as a right-bank tributary to the Mississippi River in Clayton County (fig. 1). The basin is oriented in a general northwest-southeast direction and drains $1,684 \mathrm{mi}^{2}$ (Larimer, 1957, p. 102). The Little Turkey River in Fayette County and the Volga River in Clayton County are principal tributaries to the Turkey River, with drainage areas of 355 and $403 \mathrm{mi}^{2}$, respectively (Larimer, 1957, p. 146 and 101). Land use in the basin is primarily agricultural with some livestock and timber operations.

The majority of the Turkey River Basin lies within two landform regions of the State, the Iowan Surface and the Paleozoic Plateau (fig. 1) (Prior, 1991, p. 31-34). In the extreme southeast part of the basin, a small part of the basin lies within a third landform region, the Southern Iowa Drift Plain. The topography of the Turkey River Basin developed as a result of repeated continental glacial advances across northeast Iowa, during which the land was scoured and thick deposits of glacial till were deposited. Periods of glaciation were followed by interglacial periods of erosion. The northwestern or upper part of the basin, drains the low-relief plain of the Iowan Surface landform region (Prior, 1991, p. 68-75; Horick and Soenksen, 1989, p. 8-9; Iowa Natural Resources Council, 1958, p. 3-8). Although streams draining the Iowan Surface are well established, stream gradients are low. Soils of the Iowan Surface are characterized as thin, discontinuous loess or loam and clay loam over glacial drift (Prior, 1991, p. 34; Oschwald and others, 1965, p. 41-45).

In Fayette County, the Turkey River crosses from the Iowan Surface landform region to the Paleozoic Plateau landform region. The bedrock-dominated, erosional topography of the Paleozoic Plateau is characterized by plateau-like uplands, integrated drainage networks with steep gradients, and deeply entrenched valleys (Prior, 1991, p. 34 and 84-97; Horick and Soenksen 1989, p. 6-8; Iowa Natural Resources Council, 1958, p. 3-8). Stream erosion and hillslope development have stripped away glacial deposits from all but limited areas of the Paleozoic Plateau. Karst topography occurs in the Paleozoic Plateau where carbonate rocks occur at depths of less than $50 \mathrm{ft}$ beneath the land surface. Dissolution of these carbonate rocks (limestone and dolomite) by ground water enlarges cracks and crevices in the bedrock which can result in surface depressions, sinkholes, caves, caverns, and springs. Where sinkholes have formed in streambeds, streams can abruptly disappear, as surface-water runoff is captured and redirected to ground-water flow. Soils in the Paleozoic Plateau are characterized as thin loess and glacial drift over bedrock (Prior, 1991, p. 34; Oschwald and others, 1965, p. 35-40 and 66-70).

In parts of the basin, the Turkey River and its tributaries have cut deeply into the bedrock formations. Such entrenched river valleys usually display strong bedrock control of their courses (Prior, 1991, p. 92). Where softer shales form the bedrock, the Turkey River valley may be from 1 to 2 mi wide; and where harder, more-resistant bedrock formations occur, the river valley narrows to gorge-like proportions (Iowa Natural Resources Council, 1958, p. 7-8). The lower river valley is filled with alluvium to a depth of more than $100 \mathrm{ft}$ above its rock-cut channel.

Mean annual precipitation for 1961-90 at rain gages in the Turkey River Basin was 34.15 in. at Cresco (Cresco $1 \mathrm{NE}$ ), 33.08 in. at Waucoma, $34.30 \mathrm{in.}$ at Fayette, and 33.23 in. at Elkader (Elkader 5 SSW) (Owenby and Ezell, 1992, p. 23-25). Mean annual runoff for the water years 1913-16, 1920-27, 1930, and 1933-95 in the Turkey River Basin was 8.67 in. as determined at the Turkey River at Garber streamflowgaging station (station number 05412500) (May and others, 1996, p. 70).

\section{HYDROLOGIC DATA}

Gaging-station records are the primary source of data for analyzing and understanding the flood hydrology of a river basin. Flood information is obtained from complete-record streamflow-gaging stations, which provide a continuous chronology of streamflow, and from partial-record, crest-stage streamflow-gaging 

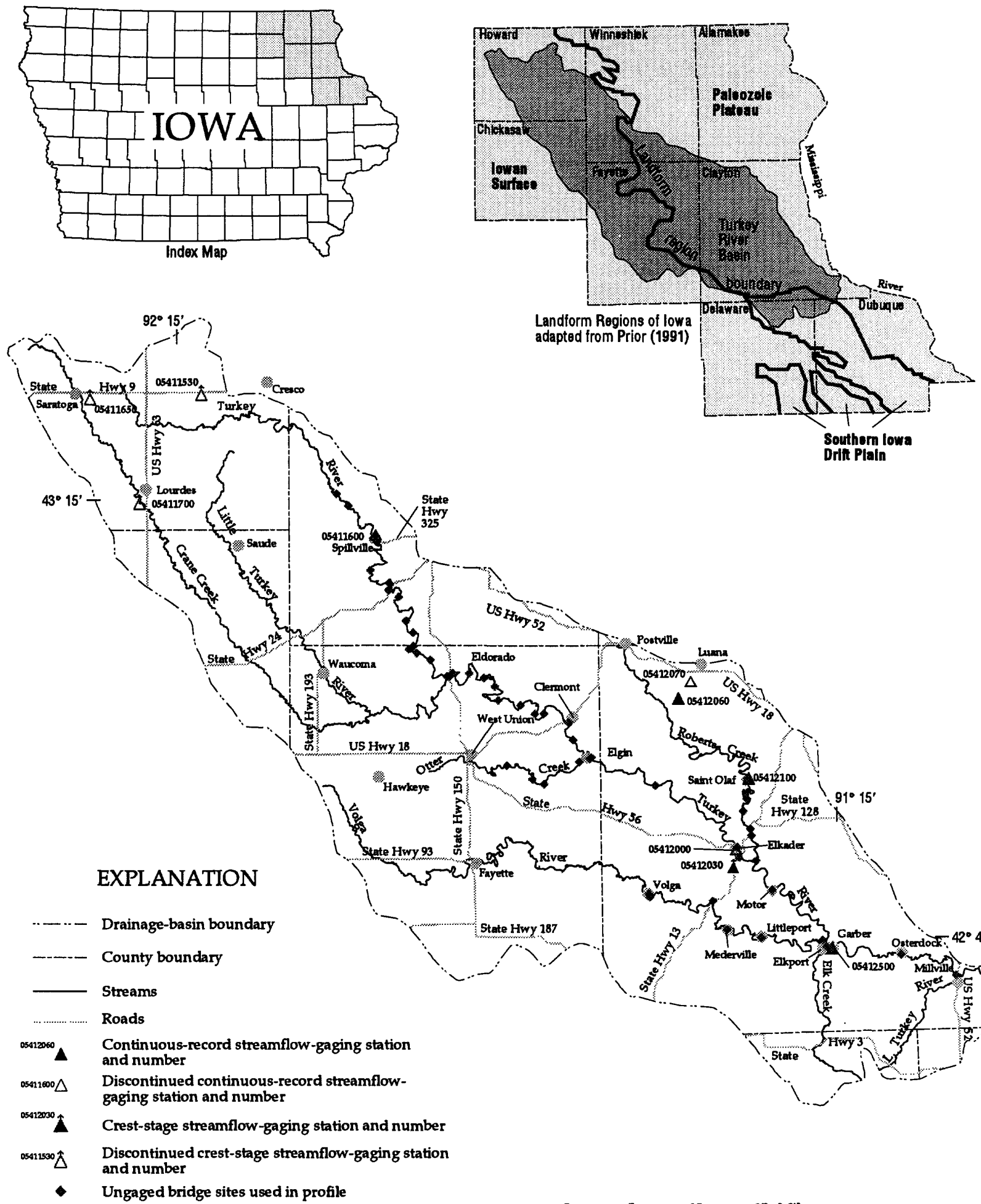

Base from U.S. Geological Survey digital data, 1:2,000,000, 1990 Universal Transverse Mercator projection,

Zone 15

Figure 1. Turkey River Basin showing location of bridge sites used in July 12, 1972, March 19, 1979, and June 15, 1991, flood profiles and U.S. Geological Survey streamflow-gaging stations. 
stations, which provide a chronology of annual peak flows. The location of 10 USGS gaging stations in the Turkey River Basin are shown in figure 1; four are active gaging stations (three continuous-record gages and one crest-stage gage) and six are discontinued gaging stations (three continuous-record gages and three crest-stage gages). The specific location, annual peak stages and discharges, and other information pertaining to each gaging station are presented in Appendix A. Discharge records collected during the operation of these gaging stations are published in the annual waterdata reports of the USGS (U.S. Geological Survey, 1915-96).

The computation of discharge records at a gaging station is dependent upon the development of a stagedischarge relation, or rating curve, between watersurface elevations (stages) and the corresponding flow rates (discharges). The high-water part of the stagedischarge relation generally remains stable if the channel downstream from the gaging station remains unchanged. Changes in the stage-discharge relation occur from time to time, either gradually or abruptly, due to changes in the stream channel that result from scour, deposition, or the growth of vegetation (Rantz and others, 1982, p. 328-360).

\section{FLOODFLOW FREQUENCIES}

The magnitude and frequency of flood discharges, or floodflow frequencies, for a streamflowgaging station are determined from a flood-frequency curve which relates observed annual-peak discharges to annual exceedance probability or recurrence interval. Annual exceedance probability is expressed as the chance that a specified flood magnitude will be exceeded in any 1 year. Recurrence interval, which is the reciprocal of the annual exceedance probability, is the statistical average number of years between exceedances of a specified flood magnitude. For example, a flood with a magnitude that is expected to be exceeded on average once during any 100 -year period (recurrence interval) has a 1-percent chance (annual exceedance probability $=0.01$ ) of being exceeded during any 1 year. This flood, commonly termed the 100-year flood, is the theoretical peak discharge against which actual flood peaks generally are compared. Although the recurrence interval represents the longterm average period between floods of a specific magnitude, rare floods could occur at shorter intervals or even within the same year.

Floodflow frequencies computed for a gaging station, and recurrence intervals determined for selected flood peaks, are statistics that can change when recalculated as more data become available. Statistics become more reliable as more data are collected and used in the computations. USGS streamflowgaging stations are the primary source of the streamflow data used in the computations.

A method for determining floodflow frequencies using streamflow-discharge data is outlined in Bulletin $17 \mathrm{~B}$ of the Interagency Advisory Committee on Water Data (1982, p. 1-28). The Interagency Advisory Committee on Water Data recommends using the Pearson Type-III distribution with log transformation of the data, commonly known as the log-Pearson Type-III distribution, as a base method for determining floodflow frequencies. At least 10 years of gaged annualpeak discharges are required to compute floodflow frequencies using this method. In this report, this method for determining floodflow frequencies is referred to as the "Bulletin 17B" method.

Other methods for determining floodflow frequencies at stream sites in Iowa, including those not gaged, are described by Lara (1987, p. 2-19) and Eash (1993, p. 9-41). Lara (1987) used the physiographic characteristics of Iowa as a guide in defining the boundaries of five hydrologic regions. Regional equations were developed by using the floodflow frequencies for all gaged stations in a hydrologically, homogeneous area, thereby reducing potential errors associated with nonrepresentative, short-term stations. For this reason, a regional analysis might produce improved estimates of the flood characteristics at gaged sites. Two new methods for estimating floodflow frequencies for stream sites in Iowa were developed by Eash (1993). Statewide, drainage-basin equations were developed by relating significant drainage-basin characteristics (quantified using a geographicinformation-system procedure) to the floodflow frequencies for 164 streamflow-gaging stations in Iowa. Secondly, statewide and regional channel-geometry equations were developed by relating significant channel-geometry characteristics (measured onsite) to the floodflow frequencies for 157 streamflow-gaging stations in Iowa. Lara (1987) and Eash (1993) both used the Bulletin 17B method as the base method for developing their flood-estimation equations.

The floodflow frequencies computed using the Bulletin 17B method, the regional method of Lara (1987), and the drainage-basin and channel-geometry characteristic methods of Eash (1993) for the gaging stations in the Turkey River Basin are listed in table 1. The flood-frequency discharges listed in table 1 were determined using available historic data and observed annual-peak discharges collected through the following water years: through the 1995 water year for the 
Bulletin 17B method, through the 1984 water year for the regional method developed by Lara (1987), and through the 1990 water year for the drainage-basin and channel-geometry methods developed by Eash (1993). It should be noted that different flood-frequency discharges might be computed for these gaging stations by other agencies using the Bulletin 17B method if analyses use different periods of record, different approaches to weighting the skewness (asymmetry) of the frequency distribution of the annual peak discharges, or different approaches to incorporation of historical flood information.

\section{FLOOD HISTORY}

Continuous records of streamflow have been collected in the Turkey River Basin in northeast Iowa from as early as August 1913, at the USGS streamflowgaging station Turkey River at Garber (station number 05412500 , fig. 1), with the exception of a few water years during the early period of record (see Appendix A). Selected flood-peak discharges, including maximum known flood-peak discharges, and recurrence intervals for the 10 streamflow-gaging stations in the Turkey River Basin are listed in table 2. The following descriptions of five floods that occurred in the Turkey River Basin include three floods (1972, 1979, and 1991) for which information on water-surfaceelevation profiles were available (Appendix B, figs. 27) and two floods (1922 and 1947) for which information on water-surface-elevation profiles were not available.

\section{Flood of February 23, 1922}

The second largest flood on record in the Turkey River Basin occurred on February 23, 1922 (the largest flood occurred on June 15, 1991). Severe thunderstorms crossed the State during February 21-23, and excessive rainfall occurred over a large area of northeastern Iowa on February 22 (U.S. Department of Agriculture, Weather Bureau, and Iowa Weather and Crop Service, 1922, p. 9). Because the rains fell on frozen ground, most of the rainfall was directed to surfacewater runoff, which caused the most severe flooding ever experienced this early in the season to occur in the Turkey River Basin. Flooding was especially severe in Allamakee, Bremer (not shown, located south of Chickasaw County), Clayton, Delaware, Fayette, and Winneshiek Counties. The flooding inundated many miles of roads and railroads. Damage to railroads was especially severe in the flooded area, with many bridges and road-beds washed out. A stretch of the Chicago, Milwaukee, and St. Paul Railroad from West Union to Turkey River Junction was reported to have been the hardest hit by the flooding, with 24 railroad bridges and several miles of track washed out. Rainfall recorded during February 21-22, 1922, at Fayette was 3.20 in. (U.S. Department of Agriculture, Weather Bureau, and Iowa Weather and Crop Service, 1922, p. 11-12).

At the Turkey River at Garber streamflowgaging station, the peak discharge $\left(32,300 \mathrm{ft}^{3} / \mathrm{s}\right)$ for the flood of February 23, 1922 (table 2), is the second largest known discharge (1902-95) and the peak stage $(28.06 \mathrm{ft})$ is the second highest since at least 1890 . The flood-peak discharge of $32,300 \mathrm{ft}^{3} / \mathrm{s}$ has a recurrence interval of approximately 45 years (table 2 ).

\section{Flood of June 13, 1947}

Severe flooding that affected much of Iowa during June 1947, also involved the Turkey River Basin. Frequent rains during April and early June saturated soils in the basin, and excessive rains over northeastern Iowa during the remainder of June caused one of the most widespread flood periods of record in this area. Most of the flooding was caused by intense, widespread thunderstorms during June 12-13, during which more than 4 in. of rain fell in the middle part of the Turkey River Basin (Iowa Natural Resources Council, 1958, p. 53-54). Rainfall amounts recorded during June 12-13, 1947, were 3.20 in. at Cresco and 3.95 in. at Elkader (U.S. Department of Commerce, Weather Bureau, and Iowa Department of Agriculture, 1947, p. 68). Urban damage was extensive, with most damage occurring on the Volga and Turkey Rivers where parts of the towns of Volga, Littleport, Elkader, and Elkport were inundated; the National Red Cross reported that flooding damaged the homes and property of 50 families in Fayette County and 100 families in Clayton County (Iowa Natural Resources Council, 1958, p. 53). The June 1947 flood in the Turkey River Basin inundated 11,871 acres and total damage was estimated at $\$ 936,875$; including damage of $\$ 438,790$ for crops and pasture, $\$ 162,055$ for rural property, and $\$ 336,030$ for urban property (Iowa Natural Resources Council, 1958, p. 72).

At the Turkey River at Spillville streamflowgaging station (station number 05411600 , fig. 1), the peak discharge $\left(10,000 \mathrm{ft}^{3} / \mathrm{s}\right)$ and stage $(18.4 \mathrm{ft})$ for the flood in June 1947 (table 2), are the largest recorded at this site during 1947-91. The flood-peak discharge at Spillville of $10,000 \mathrm{ft}^{3} / \mathrm{s}$ has a recurrence interval of 
Table 1. Floodflow frequencies for streamflow-gaging stations in the Turkey River Basin

[17B, Bulletin 17B (Interagency Advisory Committee on Water Data, 1981); Lara, hydrologic-region flood-frequency equations (Lara, 1987, p. 28); DB, drainage-basin characteristic flood-frequency equations (Eash, 1993, p. 17); CG, channel-geometry characteristic flood-frequency equations (Region I, bankfull; Eash, 1993, p. 25); --, not determined]

\begin{tabular}{|c|c|c|c|c|c|c|c|c|}
\hline \multirow{2}{*}{$\begin{array}{c}\text { Station } \\
\text { number } \\
\text { (fig. 1) }\end{array}$} & \multirow[b]{2}{*}{ Station name } & \multirow[b]{2}{*}{ Method } & \multicolumn{6}{|c|}{$\begin{array}{l}\text { Discharge, in cubic feet per second, } \\
\text { for indicated recurrence interval, in years }\end{array}$} \\
\hline & & & 2 & 5 & 10 & 25 & 50 & 100 \\
\hline \multirow[t]{4}{*}{05411530} & North Branch Turkey River near Cresco & $17 \mathrm{~B}$ & 316 & 1,080 & 2,000 & 3,770 & 5,620 & 7,970 \\
\hline & & $\operatorname{Lara}^{\mathrm{a}}$ & 1,000 & 1,920 & 2,630 & 3,650 & 4,460 & 5,330 \\
\hline & & $\mathrm{DB}$ & 650 & 1,350 & 1,940 & 2,800 & 3,530 & 4,310 \\
\hline & & CG & 533 & 1,190 & 1,770 & 2,690 & 3,450 & 4,380 \\
\hline \multirow[t]{4}{*}{05411600} & Turkey River at Spillville & $17 \mathrm{~B}$ & 2,850 & 5,410 & 7,290 & 9,770 & 11,600 & 13,500 \\
\hline & & $\operatorname{Lara}^{\mathbf{a}}$ & 3,690 & 6,800 & 9,570 & 13,000 & 15,400 & 18,500 \\
\hline & & DB & 2,580 & 4,850 & 6,640 & 9,040 & 11,000 & 13,000 \\
\hline & & CG & 2,740 & 5,300 & 7,280 & 10,200 & 12,400 & 15,000 \\
\hline \multirow[t]{4}{*}{05411650} & Crane Creek tributary near Saratoga & 17B & 633 & 1,180 & 1,580 & 2,100 & 2,500 & 2,910 \\
\hline & & $\operatorname{Lara}^{\mathrm{a}}$ & 500 & 1,010 & 1,440 & 2,060 & 2,540 & 3,080 \\
\hline & & DB & 348 & 780 & 1,170 & 1,750 & 2,260 & 2,820 \\
\hline & & CG & -- & -- & -- & -- & -- & -- \\
\hline \multirow[t]{4}{*}{05411700} & Crane Creek near Lourdes & 17B & 2,050 & 4,530 & 6,550 & 9,410 & 11,700 & 14,000 \\
\hline & & Lara $^{\mathrm{a}}$ & 2,200 & 4,090 & 5,710 & 7,820 & 9,320 & 11,200 \\
\hline & & DB & 1,560 & 3,060 & 4,280 & 5,950 & 7,320 & 8,780 \\
\hline & & CG & 1,760 & 3,550 & 4,980 & 7,120 & 8,760 & 10,800 \\
\hline \multirow[t]{4}{*}{05412000} & Turkey River at Elkader & 17B & 12,000 & 17,600 & 21,300 & 25,700 & 28,900 & 31,900 \\
\hline & & Lara $^{\mathrm{b}}$ & 12,000 & 17,600 & 21,300 & 25,700 & 28,900 & 31,900 \\
\hline & & DB & 10,000 & 17,500 & 23,200 & 30,400 & 36,100 & 42,000 \\
\hline & & CG & -- & -. & -. & - & -- & -- \\
\hline \multirow[t]{4}{*}{05412030} & French Hollow near Elkader & 17B & -- & -- & -- & -- & -- & -- \\
\hline & & Lara $^{c}$ & 404 & 808 & 1,150 & 1,630 & 2,000 & 2,410 \\
\hline & & $\mathrm{DB}$ & 709 & 1,620 & 2,430 & 3,660 & 4,750 & 5,950 \\
\hline & & $\mathrm{CG}$ & -- & -- & -- & -- & -- & -- \\
\hline \multirow[t]{4}{*}{05412060} & Silver Creek near Luana & 17B & -- & -- & -- & -- & -- & -- \\
\hline & & Lara $^{c}$ & 455 & 907 & 1,290 & 1,830 & 2,230 & 2,690 \\
\hline & & DB & 274 & 611 & 910 & 1,360 & 1,740 & 2,160 \\
\hline & & CG & -- & -- & -- & -- & -- & -- \\
\hline \multirow[t]{4}{*}{05412070} & Unnamed Creek near Luana & $17 \mathrm{~B}$ & -- & -- & -- & -- & -- & -- \\
\hline & & Lara $^{c}$ & 212 & 434 & 616 & 885 & 1,100 & 1,320 \\
\hline & & DB & 94 & 222 & 341 & 527 & 695 & 883 \\
\hline & & CG & -- & -- & -- & -- & -- & -- \\
\hline \multirow[t]{4}{*}{05412100} & Roberts Creek above Saint Olaf & 17B & -- & -- & -- & -- & -- & -- \\
\hline & & Lara $^{\mathrm{C}}$ & 2,220 & 4,180 & 5,930 & 8,190 & 9,750 & 11,800 \\
\hline & & DB & 2,070 & 4,080 & 5,720 & 7,970 & 9,820 & 11,800 \\
\hline & & CG & -- & - & -- & -- & -- & -- \\
\hline \multirow[t]{4}{*}{05412500} & Turkey River at Garber & 17B & 15,200 & 21,100 & 24,900 & 29,400 & 32,700 & 35,800 \\
\hline & & Lara $^{\mathrm{b}}$ & 15,700 & 21,000 & 24,100 & 27,800 & 30,300 & 32,700 \\
\hline & & DB & -- & -- & -- & -- & -- & -- \\
\hline & & CG & 9,170 & 15,900 & 20,600 & 27,200 & 31,600 & 37,200 \\
\hline
\end{tabular}

${ }^{a}$ Flood-frequency equations for hydrologic regions 2 and 3 were used based on weighted average, drainage-area ratios.

${ }^{b}$ Flood-frequency discharges were determined from figure 2 (Lara, 1987, p. 8).

${ }^{c}$ Flood-frequency equations for hydrologic region 2 were used. 
approximately 25 years (table 2). At the Turkey River at Garber gaging station, the peak discharge $\left(29,000 \mathrm{ft}^{3} / \mathrm{s}\right)$ for the flood in June 13,1947 (table 2), is the third largest known discharge (1902-95). The floodpeak discharge at Garber of $29,000 \mathrm{ft}^{3} / \mathrm{s}$ has a recurrence interval of approximately 25 years (table 2 ).

\section{Flood of July 12, 1972}

The flood of July 12,1972, occurred as a result of two intense localized thunderstorms on July 9 and July 12 in the upper part of the Turkey River Basin. Respective rainfall amounts recorded on July 9 and July 12, 1972, in the Turkey River Basin were as follows: at Cresco, 3.85 and 3.90 in.; at Elkader, 1.10 and 0.04 in.; at Fayette, 1.91 and 1.44 in.; and at Waucoma, 1.10 and 3.54 in. (U.S. Department of Commerce, National Oceanic and Atmospheric Administration, and Iowa Department of Agriculture, 1972, p. 97-98). The rain gage at Cresco recorded 13.69 in. during July 1972, which at the time, was the maximum monthly amount of rainfall on record for the rain gage. The flood inundated businesses in Spillville, Waucoma, and Saude; road and bridge damages in southern Howard County were reported at $\$ 350,000$ (U.S. Department of Commerce, National Oceanic and Atmospheric Administration, and Iowa Department of Agriculture, 1972, p. 97).

At the Turkey River at Spillville streamflowgaging station, the peak discharge $\left(8,600 \mathrm{ft}^{3} / \mathrm{s}\right)$ for the flood of July 12, 1972 (table 2), is the second largest recorded discharge at this site during 1947-91. The flood-peak discharge of $8,600 \mathrm{ft}^{3} / \mathrm{s}$ has a recurrence interval of approximately 17 years (table 2 ).

\section{Flood of March 19, 1979}

The March 19, 1979, flood is discussed in detail in the report "Turkey/Volga River Flood of March 19, 1979," (Iowa Natural Resources Council, 1980). The flood along the Turkey and Volga Rivers on March 19, 1979 , resulted from a rapid snowmelt that occurred over a period of several days prior to the flooding. The Iowa Natural Resources Council (1980, p. 2-3) reported that snow depths in the basin prior to the flooding were approximately 3-4 in. (snow-depth data obtained from the U.S. Army Corps of Engineers), and that the flood of March 19, 1979, was most extensive along the Turkey River from Garber to Osterdock.
At the Turkey River at Garber streamflowgaging station, the peak discharge $\left(26,000 \mathrm{ft}^{3} / \mathrm{s}\right)$ for the flood of March 19, 1979 (table 2), is the sixth largest recorded discharge at this site during 1902-95. The flood-peak discharge of $26,000 \mathrm{ft}^{3} / \mathrm{s}$ has a recurrence interval of approximately 13 years (table 2 ).

\section{Flood of June 15, 1991}

The largest flood on record in the Turkey River Basin occurred on June 15, 1991. Significant flooding also occurred during June 1991 elsewhere in Iowa in parts of the Cedar, Skunk, Nishnabotna, Boyer, and Little Sioux River Basins (basins not shown, see O'Connell and others, 1992, p. 7 and 28). Frequent rains from March through May 1991 saturated soils throughout much of Iowa, which at the time, made 1991 the second wettest spring (March to May) of record for the State (Harry Hillaker, State Climatologist, Iowa Department of Agriculture and Land Stewardship, oral and written commun., 1991). Flooding was so widespread in Iowa during March to June 1991, that by the end of June, 94 of Iowa's 99 counties were declared Federal agricultural disaster areas.

During the late afternoon hours of June 14th and into the early morning hours of the 15 th, torrential rains, averaging in excess of 6 in. and exceeding 13 in. at two sites, fell in the Turkey River Basin (Harry Hillaker, State Climatologist, Iowa Department of Agriculture and Land Stewardship, oral and written commun., 1991). The Turkey River at Garber streamflow-gaging station recorded an increase in stage of $21 \mathrm{ft}$ in 20 hours during the flood. Postville, in southwestern Allamakee County, recorded 4.30 in. of rainfall, the greatest official rainfall amount recorded during the storm. Other official 24-hour rainfalls recorded in the Turkey River Basin on June 15, 1991 (between 7 and 8 a.m.), were 0.92 in. at Cresco, 3.28 in. at Elkader, 2.16 in. at Fayette, and 3.05 in. at Waucoma; however, unofficial totals of 13 in. were reported at Monona in northern Clayton County and in northern Fayette County (U.S. Department of Commerce, National Oceanic and Atmospheric Administration, and Iowa Department of Agriculture and Land Stewardship, 1991, p. 6 and 31). Rainfall amounts recorded at two USGS rain gages during July 14-15 were 13.96 in. at the Unnamed Creek near Luana streamflowgaging station (station number 05412070 , fig. 1) and $9.28 \mathrm{in}$. at a site located approximately $5 \mathrm{mi}$ south of Postville (Kalkhoff and Kuzniar, 1994, p. 33-34). 


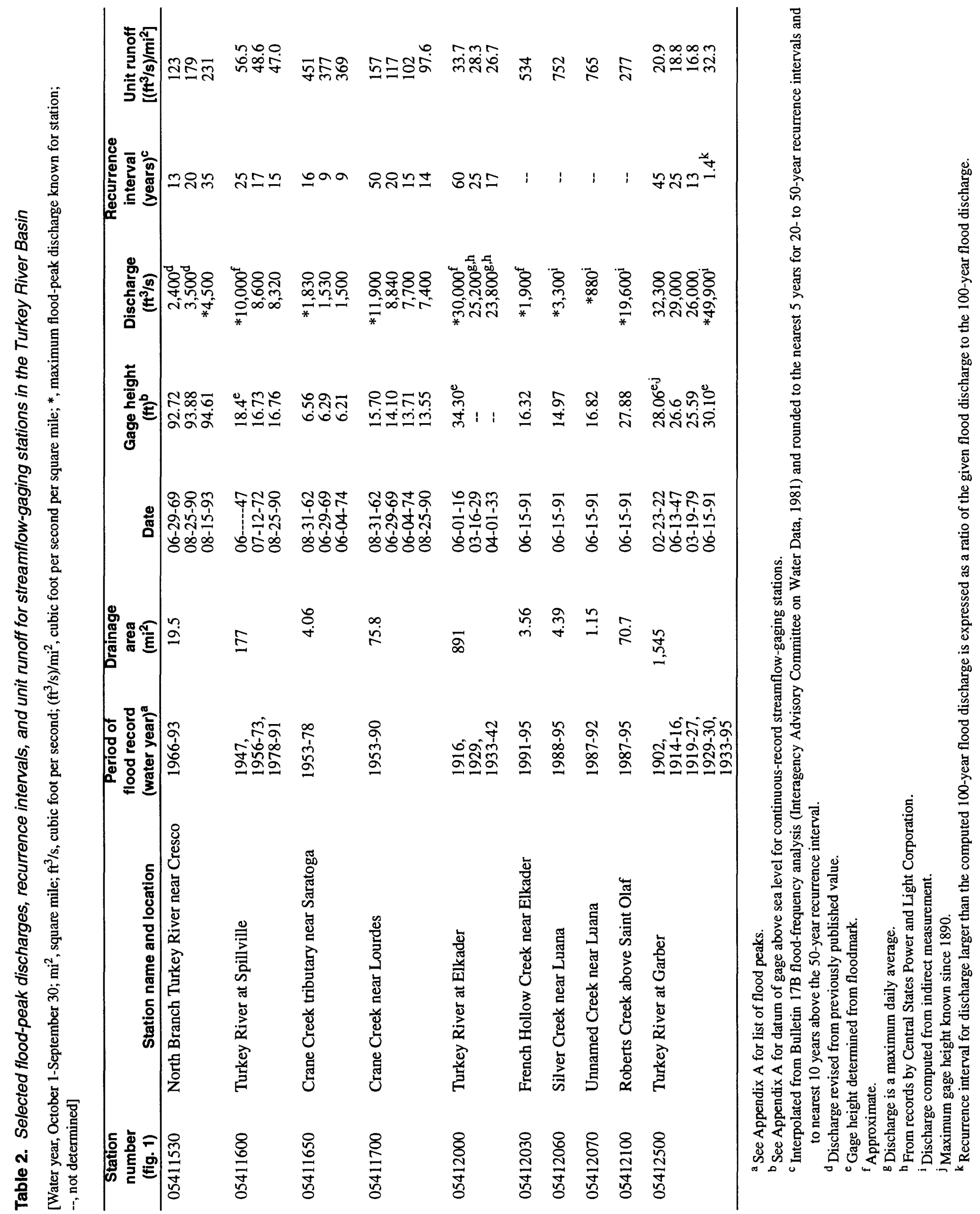


In northern Clayton County, an unofficial report of 5 in. of rain in a 2-hour period, received late in the afternoon of June 14th, prompted the National Weather Service to issue a flash flood warning (U.S. Department of Commerce, National Oceanic and Atmospheric Administration, and National Weather Service, Storm Summary Report, 1991, p. 10-11). Radar showed an east-west line of thunderstorms "training" eastward across northeast Iowa. As the evening of June 14th progressed, flash flooding developed over a large area from Clayton County west to southern Cerro Gordo County (not shown, located in north-central Iowa). Rainfall reports of 2 to 5 in. in 3 hours or less were common across this area as a result of the storm. The most intense rainfall was in Fayette County, where many areas of the county received about 5 in. of rain, and some areas in the county received up to $10 \mathrm{in}$. The towns of Hawkeye and West Union, in Fayette County, received 9 and 10 in. of rainfall, respectively.

During the flood of June 15th in Elgin, in northeast Fayette County, two 20,000-gallon storage tanks of anhydrous ammonia that were cradled on concrete foundations and an estimated 25 1,000-gallon "nurse tanks" of ammonia were swept away from a local business by the rising waters of Otter Creek (Des Moines Register, June 16, 1991; Fayette County Union, June 19, 1991). When one of the tanks struck a bridge in Elgin at about 10 a.m. and began leaking ammonia, an estimated 400 residents were evacuated. Anhydrous ammonia, a fertilizer and a deadly gas, is stored as a liquid at very cold temperatures or under pressure and vaporizes in the air. The Iowa Department of Natural Resources notified officials in Elkader, located approximately 19 mi downstream of Elgin in Clayton County, that the floating ammonia tanks might possibly be washed down the Turkey River and get caught in the undertow of the Elkader dam and rupture (Clayton County Register, June 19, 1991). As a safety precaution, the downtown area of Elkader was evacuated for a few hours and the Keystone Arch Bridge was closed on June 15th. As it turned out, observation aircraft were unable to spot any tanks floating down the river and the all-clear was given in downtown Elkader at midafternoon.

Damage from the flood was severe in Clayton and Fayette Counties. In Clayton County, three bridges were destroyed, 15 other bridges and culverts were severely damaged, and many roads were washed out by the flood; preliminary assessments of damage to roads and bridges in Clayton County were estimated to be from $\$ 1$ to $\$ 1.5$ million (Jerry Weber, Clayton County Engineer, Clayton County Register, June 19, 1991). During the flood, most roads into Elkader were inundated, cutting off travel to the town (Des Moines Reg- ister, June 16, 1991). In Elkader, city water service was interrupted by the flood when a water main in town was washed out; as were sewer services, when floodwater inundated two of the city's four sewage treatment lift stations (Clayton County Register, June 19, 1991). Ken Lemka, Elkader City Clerk, reported, "To our knowledge this is the worst flood the town's ever had, but we had enough warning from Elgin upstream that this was coming so we could be ready for it. We knew there was no way we could control it, so we just got people out of the way" (Des Moines Register, June 18, 1991). Floodwaters from the Turkey River inundated 35 homes and 38 businesses in Elkader, and floodwaters from tributaries to the Turkey River inundated 20 homes in Garber and 21 homes in Elkport (Owen Pufahl, Director, Clayton County Civil Disaster Services, Telegraph Herald, June 17, 1991). Most of the business district in Garber was severely flooded (U.S. Department of Commerce, National Oceanic and Atmospheric Administration, and National Weather Service, Storm Summary Report, 1991, p. 12). Preliminary estimates to repair damaged terraces in Clayton County were at least $\$ 100,000$; an estimated 32,000 acres of corn, soybeans, alfalfa, and oats were destroyed or damaged (Frank Phippen, Clayton County Agriculture Stabilization and Conservation Service, Telegraph Herald, June 18, 1991; Clayton County Register, June 19, 1991). Preliminary estimates of total flood damage in Clayton County were in excess of $\$ 3$ million (U.S. Department of Commerce, National Oceanic and Atmospheric Administration, and National Weather Service, Storm Summary Report, 1991, p. 11).

In Fayette County, 15 bridges were washed out and nearly all roads in the county were closed at one time or another during the flood (U.S. Department of Commerce, National Oceanic and Atmospheric Administration, and National Weather Service, Storm Summary Report, 1991, p. 11). Preliminary estimates of total damage in Fayette County were $\$ 2.1$ million (does not include agricultural damage), which included damage of $\$ 1.3$ million to private property and $\$ 0.8$ million to public property; the damage estimate included damage to 65 homes, businesses, and churches in Elgin estimated at \$1 million, and another $\$ 100,000$ to public properties; West Union's loss was estimated at $\$ 350,000$, including $\$ 250,000$ to homes and businesses; damage in Fayette was estimated at $\$ 100,000$ and in Hawkeye at $\$ 12,500$; damage to county parks was estimated to be $\$ 275,000$; and damage to county roads and bridges was estimated to be $\$ 250,000$ (Fayette County Union, June 19, 1991). Damage to agricultural terraces in Fayette County was estimated to be another $\$ 250,000$ (U.S. Department of Commerce, National Oceanic and Atmospheric 
Administration, and National Weather Service, Storm Summary Report, 1991, p. 11).

Soil erosion was severe as a result of the flood, with top soil losses as high as 200-250 tons per acre (U.S. Department of Commerce, National Oceanic and Atmospheric Administration, and National Weather Service, Storm Summary Report, 1991, p. 11-12). Reports indicated that a few farms were completely destroyed as intense rain and runoff eroded soils down to bedrock. Crops along river flood plains and creeks in the Turkey River Basin were destroyed. No one was killed or seriously injured by the flooding; however, several hundred head of livestock were swept away and drowned (Des Moines Register, June 18, 1991).

The discharge from the June 15, 1991, flood on the Turkey River at Garber streamflow-gaging station is the largest known peak discharge $\left(49,900 \mathrm{ft}^{3} / \mathrm{s}\right.$, determined from an indirect measurement) at this site for the period 1902-95 (table 2), and the peak stage (30.10 ft) is the highest since at least 1890 . The flood-peak discharge of $49,900 \mathrm{ft}^{3} / \mathrm{s}$ is 1.4 times larger than the Bulletin 17B, 100-year recurrence-interval discharge (table 2). The peak stage at this gage associated with this flood exceeded the flood stage by about $13.1 \mathrm{ft}$. The flood was limited to the middle and lower parts of the Turkey River Basin, as indicated by the streamflow record at the Turkey River at Spillville gaging station, where the peak discharge on June 15,1991 , was only $462 \mathrm{ft}^{3} / \mathrm{s}$.

\section{FLOOD PROFILE}

Water-surface-elevation profiles for the floods of July 12, 1972, March 19, 1979, and June 15, 1991, in the Turkey River Basin in northeast Iowa, are shown in Appendix B (figs. 2-7). Water-surface elevations for the floods of July 12,1972, and June 15, 1991, were collected by the USGS; except for two supplemental water-surface elevations of the flood of June 15, 1991, discussed in text below. Water-surface elevations for the flood of March 19, 1979, were collected by the Iowa Natural Resources Council and information on the collection of these flood elevations is described in the report "Turkey/Volga River Flood of March 19, 1979" (Iowa Natural Resource Council, 1980, p. 12). Profiles for the flood of March 19, 1979, are presented in this report for comparative purposes.

Flood elevations collected by the USGS, located both immediately downstream and 1 bridge-length upstream from selected bridges, were identified within a few days of passage of the flood peak and were referenced to a common datum by differential leveling.
Low-water profiles measured on July 1-2, 1981, and on September 21-22, 1992, also are shown in figures 2-7 to indicate the approximate low-end of the range of stage that can occur within the profiled reaches.

The profiles were defined using data obtained by the USGS, with the following two exceptions: (1) the profiles of the flood of March 19, 1979, along the Turkey and Volga Rivers (figs. 2-4), were defined using water-surface elevations collected by the Iowa Natural Resources Council (1980, p. 12); and (2) the profiles of the flood of June 15, 1991, and low water September 22, 1992, along the Turkey River in Elkader (figs. 2 and $3 \mathrm{C}$ ), were supplemented by water-surface elevations obtained from Rust Environment and Infrastructure, Waterloo, Iowa (Doug Schindel, Engineer, Rust Environment and Infrastructure, written commun., August 1996) to better define the water-surface elevations in the vicinity of the two dams in Elkader (one upstream and one downstream of the Keystone Arch bridge in Elkader). The water-surface elevations noted as supplemental on figure $3 \mathrm{C}$ were obtained from correlation profiles prepared by Rust Environment and Infrastructure. The supplemental low-water elevations (fig. 3C) were collected on December 1, 1994.

Profiles between the bridges, and between the upstream and downstream sides of individual bridges, are straight-line interpolations which provide only an approximation of the water-surface elevations. While water-surface elevations for the 1972, 1979, and 1991 floods were collected at the majority of the bridges listed along the profiled reaches in figures 2-7, it should be noted that flood elevations were not collected at every bridge, nor were flood elevations necessarily collected at both the upstream and downstream sides of each bridge.

River miles, measured from the most current 1:24,000-scale USGS topographic maps using a geographic-information-system method, are referenced to the mouth of each of the four river reaches profiled (Turkey and Volga Rivers, and Roberts and Otter Creeks). Measurements of river miles using larger- or smaller-scale cartographic data or different measurement methods may yield different values than those contained in this report. Water-surface elevations collected by the Iowa Natural Resources Council (1980, p. 12) for the flood of March 19, 1979 (figs. 2-4), and by Rust Environment and Infrastructure for the flood of June 15, 1991, and low water December 1, 1994 (figs. 2 and $3 \mathrm{C}$ ), were profiled using river miles measured by the USGS. Bridges are designated by an index number that helps to identify their location. For example, 9102-12 SW refers to a location in Township 91 North, Range 02 West, southwest quarter of section 12 . 
Differential leveling was performed to reference all the points along the profiles to a common datum, sea level. A bench mark and a reference point were established at the majority of the bridges in the profiled reach. Bench-mark and reference-point descriptions and elevations for bridge sites used in the June 15, 1991, flood profile are listed in Appendix C.

For bridges used in the June 15, 1991, flood profile, bridge-deck and low-bridge-chord elevations are shown in figures 2-7 to indicate the relation between the elevation of important components of the bridges and the elevation of the profiled flood and low-water. For sloping bridges, the profiled bridge-deck and lowbridge-chord elevations represent the lower ends of the bridges.

\section{CONSIDERATIONS}

The user of this report is cautioned that the stagedischarge data presented herein are representative of the physical conditions of the basin at the time of the floods described. Changes in the basin can alter the flood magnitude for a specific frequency. Examples of these basin changes include, but are not limited to, extensive urbanization, implementation of agricultural conservation practices, and installation of drainage systems. Changes in the channel conditions immediately downstream from a streamflow-gaging station can substantially affect the stage-discharge relation. Examples of such changes include the construction of dams, bridges, or levees; changes in the flood-plain vegetative cover; straightening of the channel; and natural scour and fill. Temporary changes can be caused by ice and debris jams that produce backwater conditions and can cause the water-surface elevations to plot higher than the normal profile.

\section{SUMMARY}

This report provides information on the floods of July 12, 1972, March 19, 1979, and June 15, 1991, in the Turkey River Basin in northeast Iowa. The June 15, 1991, flood on Turkey River at Garber (station number 05412500 ) is the largest known flood-peak discharge at the streamflow-gaging station for the period 1902-95. The peak discharge for June 15,1991 , of 49,900 cubic feet per second was 1.4 times larger than the 100-year recurrence-interval discharge. The report provides information on flood stages and discharges and floodflow frequencies for streamflow-gaging stations in the Turkey River Basin using flood information collected during 1902-95. Information on temporary bench marks and reference points established in the Turkey River Basin during 1981, 1992, and 1996 also is included in the report. A flood history describes rainfall conditions for floods that occurred during 1922, 1947, 1972, 1979, and 1991.

\section{REFERENCES}

Clayton County Register, 1991, June 19, newspaper article.

Des Moines Register, 1991, June 16 and 18, newspaper articles.

Eash, D.A., 1993, Estimating design-flood discharges for streams in Iowa using drainage-basin and channelgeometry characteristics: U.S. Geological Survey Water-Resources Investigation Report 93-4062, 96 p.

Fayette County Union, 1991, June 19, newspaper article.

Horick, P.J., and Soenksen, P.J., 1989, Water resources of northeast Iowa: Iowa Department of Natural Resources Water Atlas 8, $133 \mathrm{p}$.

Interagency Advisory Committee on Water Data, 1982, Guidelines for determining flood flow frequency: Hydrology Subcommittee Bulletin 17B, U.S. Geological Survey, Office of Water Data Coordination, $28 \mathrm{p}$. and appendices.

Iowa Natural Resources Council, 1958, An inventory of water resources and water problems, northeastern Iowa river basins: Des Moines, Iowa, Iowa Natural Resources Council Bulletin no. 7, 74 p. 1980, Turkey/Volga River flood of March 19, 1979: Des Moines, Iowa, $25 \mathrm{p}$.

Kalkhoff, S.J., and Kuzniar, R.L., 1994, Hydrologic data for the Big Spring Basin, Clayton County, Iowa, water year 1991: U.S. Geological Survey Open-File Report 94-56, $87 \mathrm{p}$.

Lara, O.G., 1987, Method for estimating the magnitude and frequency of floods at ungaged sites on unregulated rural streams in Iowa: U.S. Geological Survey WaterResources Investigation Report 87-4132, 34 p.

Larimer, O.J., 1957, Drainage areas of Iowa streams: Iowa Highway Research Board Bulletin No. 7 (reprinted 1974), $439 \mathrm{p}$.

May, J.E., Gorman, J.G., Goodrich, R.D., Bobier, M.W., and Miller, V.E., 1996, Water resources data, Iowa, water year 1995: U.S. Geological Survey Water-Data Report IA-95-1, $390 \mathrm{p}$.

Novak, C.E., 1985, WRD data reports preparation guide: Reston, Virginia, U.S. Geological Survey, 199 p. 
O'Connell, D.J., Lambert, R.B., Matthes, W.J., and SneckFahrer, D.A., 1992, Water resources data, Iowa, water year 1991: U.S. Geological Survey Water-Data Report IA-91-1, $385 \mathrm{p}$.

Oschwald, W.R., Riecken, F.F., Dideriksen, R.I., Scholtes, W.H., and Schaller, F.W., 1965, Principal soils of Iowa: Ames, Iowa, Iowa State University, Department of Agronomy, Special Report no. 42, 77 p.

Owenby, J.R., and Ezell, D.S., 1992, Monthly station normals of temperature, precipitation, and heating and cooling degree days 1961-1990, Iowa: Asheville, N.C., National Climatic Data Center, National Oceanic and Atmospheric Administration, Climatography of the United States no. 81, $32 \mathrm{p}$.

Prior, J.C., 1991, Landforms of Iowa: Iowa City, Iowa, Iowa Department of Natural Resources, University of Iowa Press, $153 \mathrm{p}$.

Rantz, S.E., and others, 1982, Measurement and computation of streamflow--Volume 2. Computation of discharge: U.S. Geological Survey Water-Supply Paper 2175, p. 285-631.

Telegraph Herald, 1991, June 17 and 18, newspaper articles.

U.S. Department of Agriculture, Weather Bureau, and Iowa Weather and Crop Service, 1922, Climatological data, Iowa: Des Moines, Iowa, monthly summaries, v. 33, no. 2, p. 9-16.

U.S. Department of Commerce, National Oceanic and Atmospheric Administration, and Iowa Department of Agriculture, 1972, Climatological data, Iowa:

Asheville, N.C., monthly summaries, v. 83, no. 7 , p. 95-118.

U.S. Department of Commerce, National Oceanic and Atmospheric Administration, and Iowa Department of Agriculture and Land Stewardship, 1991, Climatological data, Iowa: Asheville, N.C., monthly summaries, v. 102 , no. $6,36 \mathrm{p}$.

U.S. Department of Commerce, National Oceanic and Atmospheric Administration, and National Weather Service, 1991, Storm summary report, Iowa June 1991: National Weather Service, WS Form F-2, 13 p.

U.S. Department of Commerce, Weather Bureau, and Iowa Department of Agriculture, 1947, Climatological data, Iowa: Des Moines, Iowa, monthly summaries, v. 58, no. 6 , p. 66-72.

U.S. Geological Survey, 1915-96, Water resources data, Iowa, water years 1915-95 (published annually):

U.S. Geological Survey Water-Data Reports. 


\section{APPENDIX A}

\section{PEAK STAGES AND DISCHARGES FOR STREAMFLOW-GAGING STATIONS IN THE TURKEY RIVER BASIN, NORTHEAST IOWA, 1902-1995}

The peak-stage and discharge data for streamflowgaging stations located in the Turkey River Basin were compiled for May 18, 1902, through September 30, 1995. The peak flow data are listed in chronological order. In general, independent peak discharges above a pre-selected base (partial-duration series) are listed for the continuous-record gaging stations. The magnitude of the selected base discharge, given in the "Remarks" section of the headnote, was determined so that it would be equaled or exceeded on the average of about three times per year. Two peak discharges are considered independent if a plot of the recorded stages indicates a well-defined trough between the peaks and if the instantaneous discharge of the trough is 25 percent or more below that of the lower peak (Novak, 1985, p. 93). Only the annual peak discharges are listed for the crest-stage gaging stations.
The peak flow lists for each gaging-station are arranged in downstream order as explained in the annual water-data reports of the USGS (see "References"). The gaging stations are identified by a permanent number that also is used in figure 1 and in tables 1 and 2 of this report. The datum of the gage, when given, is above sea level. Flood stage, as determined by the National Weather Service, is the stage at which overflow of the natural banks of the stream begins to cause damage in the reach in which the elevation is measured.

Footnotes used throughout this appendix are selected so that each letter has the same meaning. For example, each occurrence of footnote " $\mathrm{f}$ " in any of the lists means "Affected by ice." Not all footnotes may appear in every list. 


\section{4}




\section{North Branch Turkey River near Cresco, Iowa}

(Discontinued September 30, 1993)

Location.--Latitude $43^{\circ} 22^{\prime} 15^{\prime \prime}$, longitude $92^{\circ} 12^{\prime} 49^{\prime \prime}$, in NW1/4 sec. 25 , T.99 N., R.12 W., Howard County, Hydrologic Unit 07060004, at bridge on State Highway 9, 5 mi west of Cresco.

Drainage area.--19.5 $\mathrm{mi}^{2}$.

Gage.--Crest-stage gage.

Stage-discharge relation.--Defined by current-meter measurements and above $200 \mathrm{ft}^{3} / \mathrm{s}$ by step-backwater computations.

Remarks.--Only annual peaks are shown.

\section{Peak stages and discharges}

[Water year, October 1-September 30; $\mathrm{ft}$, feet above gage datum; $\mathrm{ft}^{3} / \mathrm{s}$, cubic feet per second; --, not determined]

\begin{tabular}{|c|c|c|c|}
\hline Water year & Date & $\begin{array}{c}\text { Gage height } \\
\text { (ft) }\end{array}$ & $\begin{array}{c}\text { Discharge } \\
\left(\mathrm{ft}^{3} / \mathrm{s}\right)\end{array}$ \\
\hline 1966 & Mar. 4,1966 & 89.85 & $510^{\mathrm{a}}$ \\
\hline 1967 & -- & $--^{b}$ & $199^{c}$ \\
\hline 1968 & -- & $--^{b}$ & $189^{c}$ \\
\hline 1969 & June 29,1969 & 92.72 & $2,400^{\mathrm{a}}$ \\
\hline 1970 & Aug. 8,1970 & 88.25 & $130^{\mathrm{a}}$ \\
\hline 1971 & Oct. $\quad 9,1970$ & 89.86 & $510^{\mathrm{a}}$ \\
\hline 1972 & July 12,1972 & 91.47 & $1,500^{\mathrm{a}}$ \\
\hline 1973 & Apr. 17,1973 & 88.95 & $200^{\mathrm{a}}$ \\
\hline 1974 & - & -.b & $25^{\mathrm{d}}$ \\
\hline 1975 & Apr. 28,1975 & 87.73 & $90^{\mathrm{a}}$ \\
\hline 1976 & -- & $--^{b}$ & $25^{\mathrm{d}}$ \\
\hline 1977 & -- & $--b$ & $25^{\mathrm{d}}$ \\
\hline 1978 & -- & $--b$ & $25^{\mathrm{d}}$ \\
\hline 1979 & Aug. 22, 1979 & 90.70 & $1,100^{\mathrm{a}}$ \\
\hline 1980 & Sept. 22,1980 & 88.04 & ${ }_{11} 0^{\mathrm{d}}$ \\
\hline 1981 & Apr. $\quad 4,1981$ & 88.41 & $140^{\mathrm{a}}$ \\
\hline 1982 & Mar. 31,1982 & 88.28 & $130^{\mathrm{a}}$ \\
\hline 1983 & Nov. 12,1982 & 92.19 & $2,100^{\mathrm{a}}$ \\
\hline 1984 & June 17,1984 & 91.83 & $1,740^{\mathrm{a}}$ \\
\hline 1985 & -- & 87.33 & $65^{\mathrm{a}}$ \\
\hline 1986 & Mar. 19, 1986 & 90.21 & $700^{a}$ \\
\hline 1987 & Oct. 12,1986 & 90.06 & $640^{\mathrm{a}}$ \\
\hline 1988 & -- & $--^{b}$ & $25^{\mathrm{d}}$ \\
\hline 1989 & Mar. 12,1989 & 88.06 & $110^{\mathrm{a}}$ \\
\hline 1990 & Aug. 25,1990 & 93.88 & $3,500^{\mathrm{a}}$ \\
\hline 1991 & May 18,1991 & 90.06 & $640^{\mathrm{a}}$ \\
\hline 1992 & Mar. 10,1992 & 89.75 & $450^{\mathrm{a}}$ \\
\hline 1993 & Aug. 15, 1993 & 94.61 & $4,500^{\mathrm{a}}$ \\
\hline
\end{tabular}

\footnotetext{
${ }^{\mathrm{a}}$ Discharge revised from previously published value.

${ }^{\mathrm{b}}$ Peak did not reach bottom of gage.

c Approximate.

${ }^{\mathrm{d}}$ Discharge less than indicated value.
} 


\section{Turkey River at Spillville, Iowa}

(Discontinued September 30,1991)

Location.--Latitude $43^{\circ} 12^{\prime} 28^{\prime \prime}$, longitude 91'56'56", in SW1/4 NE1/4 sec. 19, T.97 N., R.9 W., Winneshiek County, Hydrologic Unit 07060004, on right bank $60 \mathrm{ft}$ downstream from bridge on County Road W14 at north edge of Spillville, $150 \mathrm{ft}$ downstream from old mill dam, $0.6 \mathrm{mi}$ upstream from Wonder Creek, and 110.9 mi upstream from mouth.

Drainage area.--177 $\mathrm{mi}^{2}$.

Gage.--Water-stage recorder. Datum of gage is $1034.92 \mathrm{ft}$ above sea level.

Stage-discharge relation.--Defined by current-meter and indirect measurements.

Bankfull stage.--12 ft.

Remarks.--Base for partial-duration series, $1,200 \mathrm{ft}^{3} / \mathrm{s}$; prior to 1966 , peak base was $1,700 \mathrm{ft}^{3} / \mathrm{s}$.

Peak stages and discharges

[Water year, October 1-September 30; $\mathrm{ft}$, feet above gage datum; $\mathrm{ft}^{3} / \mathrm{s}$, cubic feet per second; --, not determined]

\begin{tabular}{|c|c|c|c|}
\hline Water year & Date & $\begin{array}{c}\text { Gage height } \\
\text { (ft) }\end{array}$ & $\begin{array}{c}\text { Discharge } \\
\left(\mathrm{ft}^{3} / \mathrm{s}\right)\end{array}$ \\
\hline 1947 & June 1947 & $18.4^{\mathrm{e}}$ & $10,000^{\mathrm{c}}$ \\
\hline \multicolumn{4}{|c|}{ (Systematic operation of gage began in June 1956) } \\
\hline 1956 & July 31,1956 & 4.13 & 398 \\
\hline 1957 & July 16,1957 & 6.73 & 1,230 \\
\hline 1958 & Feb. 24,1958 & $5.17^{\mathrm{f}}$ & $500^{c}$ \\
\hline \multirow[t]{2}{*}{1959} & Mar. 29, 1959 & $11.48^{\mathrm{f}}$ & -- \\
\hline & Mar. 30, 1959 & 9.12 & 2,100 \\
\hline \multirow[t]{3}{*}{1960} & Mar. 30,1960 & 10.70 & 3,220 \\
\hline & May 7,1960 & 9.18 & 2,360 \\
\hline & June 24,1960 & 10.12 & 2,860 \\
\hline 1961 & Mar. 27, 1961 & 14.37 & 6,420 \\
\hline \multirow[t]{3}{*}{1962} & Mar. 29,1962 & 15.32 & 7,380 \\
\hline & Apr. $\quad 6,1962$ & 7.57 & 1,740 \\
\hline & Aug. 31,1962 & 14.34 & 5,950 \\
\hline 1963 & Mar. 17,1963 & 8.41 & 2,000 \\
\hline 1964 & Apr. $\quad 2,1964$ & 7.25 & 1,430 \\
\hline \multirow[t]{5}{*}{1965} & Mar. $\quad 1,1965$ & $6.11^{\mathrm{f}}$ & $3,900^{c}$ \\
\hline & Apr. 1,1965 & $12.58^{f}$ & $2,800^{\mathrm{c}}$ \\
\hline & Apr. $\quad 5,1965$ & 11.56 & 2,740 \\
\hline & Apr. $\quad 8,1965$ & 11.68 & 2,810 \\
\hline & Sept. 29,1965 & 11.68 & 3,490 \\
\hline \multirow[t]{3}{*}{1966} & Feb. $\quad 8,1966$ & $12.36^{\mathrm{f}}$ & -- \\
\hline & Feb. $\quad 9,1966$ & 12.24 & 3,120 \\
\hline & July 14,1966 & 11.88 & 2,960 \\
\hline \multirow[t]{2}{*}{1967} & Mar. 10, 1967 & $9.73^{\mathrm{f}}$ & - \\
\hline & Mar. 27,1967 & 9.53 & 1,810 \\
\hline 1968 & July 24,1968 & 9.29 & 1,720 \\
\hline
\end{tabular}


05411600 Turkey River at Spillville, Iowa

Peak stages and discharges--Continued

\begin{tabular}{|c|c|c|c|}
\hline Water year & Date & $\begin{array}{c}\text { Gage height } \\
\text { (ft) }\end{array}$ & $\begin{array}{c}\text { Discharge } \\
\left(\mathrm{ft}^{3} / \mathrm{s}\right)\end{array}$ \\
\hline \multirow[t]{3}{*}{1969} & Apr. $\quad 5,1969$ & 9.34 & 1,740 \\
\hline & June 26,1969 & 15.59 & 6,990 \\
\hline & June 29,1969 & 14.80 & 6,220 \\
\hline 1970 & Aug. 9,1970 & 6.78 & 1,130 \\
\hline \multirow[t]{2}{*}{1971} & Oct. 10,1970 & 12.20 & 4,130 \\
\hline & Apr. $\quad 1,1971$ & 11.66 & 3,760 \\
\hline \multirow[t]{4}{*}{1972} & Mar. 13,1972 & $10.01^{\mathrm{f}}$ & $1,800^{c}$ \\
\hline & July 12,1972 & 16.73 & 8,600 \\
\hline & Sept. 25,1972 & 15.92 & 7,470 \\
\hline & Sept. 29,1972 & 9.21 & 1,920 \\
\hline \multirow[t]{9}{*}{1973} & Oct. 24,1972 & 8.73 & 1,780 \\
\hline & Dec. 30,1972 & -- & $2,300^{c}$ \\
\hline & Jan. 18,1973 & $10.19^{f}$ & $1,900^{c}$ \\
\hline & Feb. $\quad 1,1973$ & $8.53^{f}$ & $1,500^{c}$ \\
\hline & Mar. 11, 1973 & 8.92 & 1,780 \\
\hline & Mar. 14,1973 & 8.56 & 1,620 \\
\hline & Apr. 16,1973 & 11.92 & 3,500 \\
\hline & May 2,1973 & 12.64 & 4,070 \\
\hline & May 8,1973 & 10.56 & 2,640 \\
\hline \multicolumn{4}{|c|}{ (Gage discontinued September 30,1973, reactivated October 1,1977 ) } \\
\hline \multirow[t]{3}{*}{1978} & May 11,1978 & 13.77 & 5,140 \\
\hline & June 18,1978 & 8.20 & 1,250 \\
\hline & July $\quad 6,1978$ & 10.20 & 2,340 \\
\hline \multirow[t]{5}{*}{1979} & Mar. 19, 1979 & 11.55 & 3,540 \\
\hline & Mar. 24, 1979 & 9.87 & 2,260 \\
\hline & Mar. 31, 1979 & 10.92 & 2,870 \\
\hline & May 19,1979 & 8.36 & 1,300 \\
\hline & Aug. 22, 1979 & 8.86 & 1,550 \\
\hline \multirow[t]{3}{*}{1980} & Jan. 16,1980 & $10.32^{\mathrm{f}}$ & $2,200^{c}$ \\
\hline & Mar. 16,1980 & 12.55 & 3,940 \\
\hline & Sept. 23, 1980 & 9.82 & 1,900 \\
\hline \multirow[t]{4}{*}{1981} & Apr. $\quad 4,1981$ & 8.33 & 1,290 \\
\hline & Aug. 29, 1981 & 8.30 & 1,250 \\
\hline & Aug. 30,1981 & 8.31 & 1,260 \\
\hline & Aug. 31,1981 & 10.73 & 2,690 \\
\hline \multirow[t]{4}{*}{1982} & Mar. 16,1982 & $9.81^{\mathrm{f}}$ & -- \\
\hline & Mar. 24, 1982 & 7.95 & 1,210 \\
\hline & May 28,1982 & 8.11 & 1,240 \\
\hline & Aug. 30,1982 & 9.14 & 1,700 \\
\hline
\end{tabular}




\section{Turkey River at Spillville, Iowa}

Peak stages and discharges--Continued

\begin{tabular}{|c|c|c|c|}
\hline Water year & Date & $\begin{array}{l}\text { Gage height } \\
\text { (ft) }\end{array}$ & $\begin{array}{c}\text { Discharge } \\
\left(\mathrm{ft}^{3} / \mathrm{s}\right)\end{array}$ \\
\hline \multirow[t]{10}{*}{1983} & Nov. 12,1982 & 11.88 & 3,720 \\
\hline & Dec. 6,1982 & 7.99 & 1,250 \\
\hline & Dec. 28,1982 & 10.26 & 2,550 \\
\hline & Feb. 21,1983 & 8.25 & 1,350 \\
\hline & Mar. 7, 1983 & 9.73 & 2,160 \\
\hline & Apr. 15,1983 & 9.69 & 2,070 \\
\hline & May 8,1983 & 8.32 & 1,330 \\
\hline & May 14,1983 & 9.19 & 1,500 \\
\hline & May 19,1983 & 10.00 & 1,940 \\
\hline & May 22,1983 & 10.17 & 2,040 \\
\hline \multirow[t]{2}{*}{1984} & Feb. 16,1984 & $9.77^{\mathrm{f}}$ & -- \\
\hline & June 18,1984 & 9.02 & 1,160 \\
\hline \multirow[t]{2}{*}{1985} & Feb. 24,1985 & $12.43^{\mathrm{f}}$ & 3,980 \\
\hline & Mar. 9,1985 & 10.21 & 2,480 \\
\hline \multirow[t]{2}{*}{1986} & Mar. 19, 1986 & 12.87 & 4,660 \\
\hline & Sept. 30,1986 & 12.24 & 3,970 \\
\hline \multirow[t]{2}{*}{1987} & Oct. 5,1986 & 8.90 & 1,700 \\
\hline & Oct. 12,1986 & 12.24 & 5,200 \\
\hline 1988 & Mar. 10,1988 & $--^{f}$ & 720 \\
\hline 1989 & Mar. 12,1989 & $9.61^{\mathrm{f}}$ & 800 \\
\hline \multirow[t]{4}{*}{1990} & Mar. 3,1990 & $10.42^{f}$ & 2,040 \\
\hline & Mar. 11,1990 & 9.43 & 1,920 \\
\hline & Mar. 14,1990 & 8.95 & 1,650 \\
\hline & Aug. 25, 1990 & 16.76 & 8,320 \\
\hline \multirow[t]{4}{*}{1991} & Apr. 14,1991 & 8.17 & 1,310 \\
\hline & Apr. 28,1991 & 9.01 & 1,730 \\
\hline & Apr. 29,1991 & 10.85 & 2,830 \\
\hline & May 19,1991 & 9.14 & 1,860 \\
\hline
\end{tabular}

${ }^{c}$ Approximate.

${ }^{\mathrm{e}} \mathrm{Gage}$ height determined from floodmark.

${ }^{f}$ Affected by ice. 


\section{Crane Creek tributary near Saratoga, Iowa}

(Discontinued September 30, 1978)

Location.--Latitude $43^{\circ} 22^{\prime}$, longitude $92^{\circ} 23^{\prime}$, near SE corner of sec. 21 , T.99 N., R.13 W., Howard County, Hydrologic Unit 07060004, at bridge on State Highway 9, 1 mi east of Saratoga.

Drainage area.--4.06 $\mathrm{mi}^{2}$.

Gage.--Crest-stage gage.

Stage-discharge relation.--Defined by current-meter and indirect measurements.

Remarks.--Only annual peaks are shown.

\section{Peak stages and discharges}

[Water year, October 1-September 30; ft, feet above gage datum; $\mathrm{ft}^{3} / \mathrm{s}$, cubic feet per second; --, not determined]

\begin{tabular}{|c|c|c|c|}
\hline Water year & Date & $\begin{array}{c}\text { Gage height } \\
\text { (ft) }\end{array}$ & $\begin{array}{c}\text { Discharge } \\
\left(\mathrm{ft}^{3} / \mathrm{s}\right)\end{array}$ \\
\hline 1953 & June 13,1953 & 5.77 & 1,050 \\
\hline 1954 & June 21,1954 & 5.41 & 777 \\
\hline 1955 & Mar. 15,1955 & 3.79 & 157 \\
\hline 1956 & Apr. 1,1956 & 4.43 & 316 \\
\hline 1957 & July 16,1957 & 4.44 & 320 \\
\hline 1958 & Apr. 7,1958 & 2.38 & 22 \\
\hline 1959 & Mar. 26, 1959 & 5.34 & 734 \\
\hline 1960 & June 23,1960 & 5.97 & 1,210 \\
\hline 1961 & June 26,1961 & 6.02 & 700 \\
\hline 1962 & Aug. 31,1962 & 6.56 & 1,830 \\
\hline 1963 & May 13,1963 & 4.31 & 270 \\
\hline 1964 & May 24,1964 & 3.84 & 167 \\
\hline 1965 & Sept. 30,1965 & 5.86 & 1,120 \\
\hline 1966 & July 14,1966 & 4.79 & 456 \\
\hline 1967 & June 9,1967 & 5.70 & 990 \\
\hline 1968 & May 17,1968 & 5.82 & 1,090 \\
\hline 1969 & June 29,1969 & 6.29 & 1,530 \\
\hline 1970 & Aug. 8,1970 & 4.34 & 250 \\
\hline 1971 & Oct. $\quad 9,1970$ & 5.80 & 1,030 \\
\hline 1972 & July 12,1972 & 6.01 & 1,220 \\
\hline 1973 & May 27,1973 & 5.67 & 560 \\
\hline 1974 & June 4,1974 & 6.21 & 1,500 \\
\hline 1975 & Apr. 28,1975 & 4.29 & 238 \\
\hline 1976 & -- & $--b$ & -- \\
\hline 1977 & -- & $--b$ & - \\
\hline 1978 & - & $--b$ & -- \\
\hline
\end{tabular}

\footnotetext{
${ }^{b}$ Peak did not reach bottom of gage.
} 


\section{Crane Creek near Lourdes, Iowa}

(Discontinued September 30, 1990)

Location.--Latitude 4314'57", longitude 92 $18^{\prime} 32^{\prime \prime}$, in SE1/4 NW1/4 sec. 6, T.97 N., R.12 W., Howard County, Hydrologic Unit 07060004, at bridge on State Highway 272, 1 mi southwest of Lourdes.

Drainage area.-- $75.8 \mathrm{mi}^{2}$.

Gage.--Crest-stage gage.

Stage-discharge relation.--Defined by current-meter and indirect measurements.

Remarks.--Only annual peaks are shown.

\section{Peak stages and discharges}

[Water year, October 1-September 30; $\mathrm{ft}$, feet above gage datum; $\mathrm{ft}^{3} / \mathrm{s}$, cubic feet per second; --, not determined]

\begin{tabular}{|c|c|c|c|}
\hline Water year & Date & $\begin{array}{c}\text { Gage height } \\
\text { (ft) }\end{array}$ & $\begin{array}{c}\text { Discharge } \\
\left(\mathrm{ft}^{3} / \mathrm{s}\right)\end{array}$ \\
\hline 1953 & June 13,1953 & 12.00 & 3,200 \\
\hline 1954 & June 21,1954 & 10.61 & 2,620 \\
\hline 1955 & Mar. 15,1955 & 9.35 & 1,430 \\
\hline 1956 & Apr. $\quad 1,1956$ & 9.23 & 1,330 \\
\hline 1957 & Mar. 24, 1957 & 7.60 & 580 \\
\hline 1958 & Apr. 7,1958 & 6.39 & 336 \\
\hline 1959 & Mar. 31,1959 & 9.28 & 1,370 \\
\hline 1960 & June 23,1960 & 12.13 & 5,960 \\
\hline 1961 & Mar. 26, 1961 & 11.12 & 3,890 \\
\hline 1962 & Aug. 31,1962 & 15.70 & 11,900 \\
\hline 1963 & May 13,1963 & 9.20 & 1,310 \\
\hline 1964 & Apr. 3,1964 & 8.00 & 710 \\
\hline 1965 & Sept. 30,1965 & 11.69 & 4,360 \\
\hline 1966 & July 14,1966 & 9.19 & 1,300 \\
\hline 1967 & June 10,1967 & 11.38 & 3,850 \\
\hline 1968 & July 23,1968 & 10.87 & 3,060 \\
\hline 1969 & June 29,1969 & 14.10 & 8,840 \\
\hline 1970 & May 14,1970 & 7.32 & 530 \\
\hline 1971 & Oct. $\quad 9,1970$ & 11.46 & 3,700 \\
\hline 1972 & July 12,1972 & 11.36 & 3,500 \\
\hline 1973 & Apr. 17,1973 & 10.67 & 2,750 \\
\hline 1974 & June 4,1974 & 13.71 & 7,700 \\
\hline 1975 & -- & $-{ }^{b}$ & $210^{d}$ \\
\hline 1976 & - & $--^{b}$ & $210^{d}$ \\
\hline 1977 & - & $\ldots b$ & $210^{d}$ \\
\hline 1978 & -- & $-{ }^{b}$ & $210^{\mathrm{d}}$ \\
\hline 1979 & Mar. 20, 1979 & 10.33 & 2,200 \\
\hline 1980 & Sept. 22,1980 & 11.48 & 3,750 \\
\hline
\end{tabular}




\section{Crane Creek near Lourdes, Iowa}

\section{Peak stages and discharges--Continued}

\begin{tabular}{cccc}
\hline Water year & Date & $\begin{array}{c}\text { Gage height } \\
(\mathbf{f t})\end{array}$ & $\begin{array}{c}\text { Discharge } \\
\left(\mathrm{ft}^{3} / \mathbf{s}\right)\end{array}$ \\
\hline 1981 & Aug. 31, 1981 & 10.60 & 2,600 \\
1982 & Aug. 30, 1982 & 9.29 & 1,450 \\
1983 & Nov. 12, 1982 & 10.60 & 2,650 \\
1984 & June 17, 1984 & 11.12 & 3,020 \\
1985 & Sept. 30, 1985 & 7.49 & 580 \\
1986 & Mar. 19, 1986 & 11.25 & 3,400 \\
1987 & Oct. 12, 1986 & 11.97 & 4,400 \\
1988 & -- & $--\mathrm{b}$ & $210^{\mathrm{d}}$ \\
1989 & -- & $--\mathrm{b}$ & $210^{\mathrm{d}}$ \\
1990 & Aug. 25, 1990 & 13.55 & 7,400 \\
\hline
\end{tabular}

${ }^{\mathrm{b}}$ Peak did not reach bottom of gage.

${ }^{\mathrm{d}}$ Discharge less than indicated value. 


\section{Turkey River at Elkader, Iowa}

(Discontinued September 30, 1942)

Location.--Latitude $42^{\circ} 51^{\prime} 05^{\prime \prime}$, longitude $91^{\circ} 24^{\prime} 15^{\prime \prime}$, in NW1/4 SE1/4 sec. 23 , T.93 N., R.5 W., Clayton County, Hydrologic Unit 07060004, in tailrace of Central States Power and Light Corporation's hydroelectric plant in Elkader, 2.7 mi upstream from Roberts Creek and 39.0 mi from mouth.

Drainage area.--891 $\mathrm{mi}^{2}$.

Gage.--Nonrecording. Datum of gage is $701.61 \mathrm{ft}$ above sea level.

Stage-discharge relation.--Defined by current-meter measurements.

Remarks.--Only annual peaks are shown.

\section{Peak stages and discharges}

[Water year, October 1-September 30; $\mathrm{ft}$, feet above gage datum; $\mathrm{ft}^{3} / \mathrm{s}$, cubic feet per second; --, not determined]

\begin{tabular}{cccc}
\hline Water year & Date & $\begin{array}{c}\text { Gage height } \\
(\mathbf{f t})\end{array}$ & $\begin{array}{c}\text { Discharge } \\
\left(\mathbf{f t}^{3} / \mathbf{s}\right)\end{array}$ \\
\hline 1916 & June 1, 1916 & $34.30^{\mathrm{e}}$ & $30,000^{\mathrm{c}}$ \\
1929 & Mar. 16, 1929 & -- & $25,200^{\mathrm{g}, \mathrm{h}}$ \\
1933 & Apr. 1, 1933 & -- & $23,800^{\mathrm{g}, \mathrm{h}}$ \\
& (Systematic operation of gage began in July 1933) & 6,860 \\
1934 & Jan. 22, 1934 & 12.8 & 11,400 \\
1935 & Mar. 6, 1935 & 14.0 & 9,000 \\
1936 & Mar. 11, 1936 & 26.4 & 12,300 \\
1937 & Mar. 7, 1937 & 27.5 & 13,000 \\
1938 & Feb. 5, 1938 & 14.50 & 4,970 \\
1939 & Mar. 14, 1939 & 11.50 & 19,000 \\
1940 & July 27, 1940 & 29.1 & 19,300 \\
1941 & May 31, 1941 & 29.1 & 9,200 \\
\hline
\end{tabular}

${ }^{c}$ Approximate.

${ }^{\mathrm{e}} \mathrm{G}$ age height determined from floodmark.

${ }^{\mathrm{g}}$ Discharge is a maximum daily average.

${ }^{h}$ From records by Central States Power and Light Corporation. 


\section{French Hollow Creek near Elkader, Iowa}

Location.--Latitude 4250'19”, longitude $91^{\circ} 24^{\prime} 25^{\prime \prime}$, in SW1/4, sec. 26, T.93 N., R.5 W., Clayton County, Hydrologic Unit 07060004 , at culvert on State Highway 13, 1.1 mi south of Elkader.

Drainage area.--3.56 $\mathrm{mi}^{2}$.

Gage.--Crest-stage gage.

Stage-discharge relation.--Defined by theoretical culvert rating.

Remarks.--Only annual peaks are shown.

Peak stages and discharges

[Water year, October 1-September 30; $\mathrm{ft}$, feet above gage datum; $\mathrm{ft}^{3} / \mathrm{s}$, cubic feet per second; --, not determined]

\begin{tabular}{|c|c|c|c|}
\hline Water year & Date & $\begin{array}{c}\text { Gage height } \\
\text { (ft) }\end{array}$ & $\begin{array}{c}\text { Discharge } \\
\left(\mathrm{ft}^{3} / \mathrm{s}\right)\end{array}$ \\
\hline 1990 & Aug. 25,1990 & 12.97 & $1,050^{\mathrm{c}}$ \\
\hline 1991 & June 15,1991 & *16.32 & $1,900^{\mathrm{c}}$ \\
\hline 1992 & Dec. 13,1991 & 9.46 & $150^{\mathrm{c}}$ \\
\hline 1993 & July 11,1993 & 11.92 & $650^{c}$ \\
\hline 1994 & July 20,1994 & 10.13 & $250^{c}$ \\
\hline 1995 & Apr. 19,1995 & 9.48 & $150^{\mathrm{c}}$ \\
\hline
\end{tabular}

${ }^{c}$ Approximate.

*Gage height at gage $55 \mathrm{ft}$ upstream of culvert entrance, all other gage heights at gage $30 \mathrm{ft}$ upstream of culvert entrance. 


\section{Silver Creek near Luana, Iowa}

Location.--Latitude $43^{\circ} 01^{\prime} 19^{\prime \prime}$, longitude $91^{\circ} 29^{\prime} 21^{\prime \prime}$, in NE1/4 sec. 25, T.95 N., R.6 W., Clayton County, Hydrologic Unit 07060004, on right upstream bank at bridge on County Road W70, 2.3 mi south of Highway 52 and 18, and 3.2 mi south of Luana.

Drainage area.--4.39 $\mathrm{mi}^{2}$.

Gage.--Water-stage recorder.

Stage-discharge relation.--Defined by current-meter and indirect measurements.

Remarks.--Base for partial-duration series, $50 \mathrm{ft}^{3} / \mathrm{s}$.

Peak stages and discharges

[Water year, October 1-September 30; $\mathrm{ft}$, feet above gage datum; $\mathrm{ft}^{3} / \mathrm{s}$, cubic feet per second; --, not determined]

\begin{tabular}{|c|c|c|c|}
\hline Water year & Date & $\begin{array}{c}\text { Gage height } \\
\text { (ft) }\end{array}$ & $\begin{array}{c}\text { Discharge } \\
\left(\mathrm{ft}^{3} / \mathrm{s}\right)\end{array}$ \\
\hline 1988 & Mar. $\quad 1,1988$ & 6.45 & 63.0 \\
\hline 1989 & Mar. 11,1989 & $8.78^{f}$ & 181 \\
\hline 1990 & Mar. 8,1990 & 8.21 & 299 \\
\hline \multirow[t]{5}{*}{1991} & Apr. 12,1991 & 6.77 & 53.0 \\
\hline & Apr. 14,1991 & 6.87 & 64.0 \\
\hline & June 14,1991 & 13.64 & 1,860 \\
\hline & June 15,1991 & 14.97 & $3,300^{i}$ \\
\hline & Sept. 12,1991 & 9.30 & 468 \\
\hline \multirow[t]{10}{*}{1992} & Nov. 1,1991 & 7.23 & 182 \\
\hline & Nov. 18,1991 & 6.65 & 111 \\
\hline & Jan. 22,1992 & 6.44 & 62.0 \\
\hline & Feb. $\quad 3,1992$ & 6.82 & 140 \\
\hline & Dec. 12,1991 & 6.60 & 101 \\
\hline & Feb. 20,1992 & 6.52 & 79.0 \\
\hline & Apr. 20,1992 & 7.68 & 233 \\
\hline & Sept. 6,1992 & 6.76 & 134 \\
\hline & Sept. 9,1992 & 6.53 & 81.0 \\
\hline & Sept. 14,1992 & 6.91 & 149 \\
\hline \multirow[t]{10}{*}{1993} & Mar. 16,1993 & 7.20 & 141 \\
\hline & Mar. 30, 1993 & 8.89 & 340 \\
\hline & Mar. 31,1993 & 8.34 & 268 \\
\hline & June 17,1993 & 9.97 & 533 \\
\hline & June 29,1993 & 11.58 & 960 \\
\hline & July $\quad 9,1993$ & 7.00 & 107 \\
\hline & July 11,1993 & 10.78 & 731 \\
\hline & Aug. 15,1993 & 7.90 & 215 \\
\hline & Aug. 18, 1993 & 6.35 & 53.0 \\
\hline & Aug. 23, 1993 & 6.50 & 58.0 \\
\hline \multirow[t]{3}{*}{1994} & Feb. 19,1994 & $7.92^{f}$ & -- \\
\hline & Mar. 5, 1994 & 7.77 & 200 \\
\hline & July 20,1994 & 6.60 & 52.0 \\
\hline \multirow[t]{2}{*}{1995} & Feb. 20,1995 & 6.33 & 57 \\
\hline & Mar. 11,1995 & 6.67 & 115 \\
\hline
\end{tabular}




\section{Unnamed Creek near Luana, Iowa}

(Discontinued September 30,1992)

Location.--Latitude $43^{\circ} 02^{\prime} 24^{\prime \prime}$, longitude $91^{\circ} 28^{\prime} 07^{\prime \prime}$, in SE1/4 sec. 18, T.95 N., R.5. W., Clayton County, Hydrologic Unit 07060004, on right upstream bank at culvert on the north-south gravel road between County Road W70 and County Road X16, 0.8 mi south of State Highway 52 and 18 and approximately 1.6 mi south of Luana.

Drainage area.--1.15 $\mathrm{mi}^{2}$.

Gage.--Water-stage recorder.

Stage-discharge relation.--Defined by current-meter and indirect measurements.

Remarks.--Base for partial-duration series, $25 \mathrm{ft}^{3} / \mathrm{s}$.

\section{Peak stages and discharges}

[Water year, October 1-September 30; $\mathrm{ft}$, feet above gage datum; $\mathrm{ft}^{3} / \mathrm{s}$, cubic feet per second; --, not determined]

\begin{tabular}{cccc}
\hline Water year & Date & $\begin{array}{c}\text { Gage height } \\
(\mathbf{f t})\end{array}$ & $\begin{array}{c}\text { Discharge } \\
\left.\mathbf{f t}^{\mathbf{3}} / \mathbf{s}\right)\end{array}$ \\
\hline 1987 & Aug. 13, 1987 & 11.81 & 96.0 \\
1988 & Mar. 1, 1988 & $11.84^{\mathrm{f}}$ & 65.0 \\
1989 & Mar. 11, 1989 & $11.46^{\mathrm{f}}$ & -- \\
& Mar. 14, 1989 & 11.45 & 43.0 \\
1990 & Aug. 25, 1990 & 11.99 & 110 \\
1991 & May 29, 1991 & 11.13 & 45.0 \\
& May 30, 1991 & 10.93 & 35.0 \\
& June 14, 1991 & 15.24 & 365 \\
& June 15, 1991 & 16.82 & $880^{\mathrm{i}}$ \\
& Sept. 12, 1991 & 12.85 & 169 \\
& Apr. 20,1992 & 11.12 & 37.0 \\
& Sept. 9, 1992 & 11.31 & 45.0 \\
& Sept. 14, 1992 & 11.20 & 40.0 \\
\hline
\end{tabular}

${ }^{\mathrm{f}}$ Affected by ice.

${ }^{\mathrm{i}}$ Discharge computed from indirect measurement. 


\section{Roberts Creek above Saint Olaf, Iowa}

Location.--Latitude 4255'49", longitude 91 ${ }^{\circ} 23^{\prime} 03^{\prime \prime}$, in SW1/4 NW1/4 sec. 25, T.94 N., R.5 W., Clayton County, Hydrologic Unit 07060004 , on left downstream bank at bridge on road X28, 0.1 mi north of county road B65, on north edge of Saint Olaf.

Drainage area.--70.7 $\mathrm{mi}^{2}$.

Gage.--Water-stage recorder. Datum of gage is $826.73 \mathrm{ft}$ above sea level.

Stage-discharge relation.--Defined by current-meter and indirect measurements.

Remarks.--Base for partial-duration series, $500 \mathrm{ft}^{3} / \mathrm{s}$.

\section{Peak stages and discharges}

[Water year, October 1-September 30; ft, feet above gage datum; $\mathrm{ft}^{3} / \mathrm{s}$, cubic feet per second; --, not determined]

\begin{tabular}{|c|c|c|c|}
\hline Water year & Date & $\begin{array}{c}\text { Gage height } \\
\text { (ft) }\end{array}$ & $\begin{array}{c}\text { Discharge } \\
\left(\mathrm{ft}^{3} / \mathrm{s}\right)\end{array}$ \\
\hline \multicolumn{4}{|c|}{ (Operated as a low-flow station only, September 1957 to July 1977 ) } \\
\hline 1987 & Sept. 17,1987 & 13.02 & 513 \\
\hline 1988 & Mar. 2,1988 & $12.68^{\mathrm{f}}$ & 270 \\
\hline 1989 & Mar. 11, 1989 & $15.77^{\mathrm{f}}$ & 1,020 \\
\hline 1990 & Aug. 25, 1990 & 14.88 & 758 \\
\hline \multirow[t]{2}{*}{1991} & Apr. 12,1991 & 14.45 & 625 \\
\hline & June 15,1991 & 27.88 & $19,600^{\mathrm{i}}$ \\
\hline \multirow[t]{2}{*}{1992} & Nov. 1,1991 & 17.46 & 2,120 \\
\hline & Apr. 21,1992 & 14.96 & 628 \\
\hline \multirow[t]{8}{*}{1993} & Mar. 31, 1993 & 16.72 & 2,120 \\
\hline & June 18,1993 & 14.48 & 726 \\
\hline & June 30,1993 & 15.86 & 1,530 \\
\hline & July $\quad 9,1993$ & 14.41 & 714 \\
\hline & July 11,1993 & 16.08 & 1,740 \\
\hline & July 17,1993 & 14.92 & 935 \\
\hline & Aug. 15,1993 & 13.77 & 517 \\
\hline & Aug. 23, 1993 & 13.95 & 572 \\
\hline 1994 & Mar. 5,1994 & $15.78^{f}$ & 1,280 \\
\hline 1995 & Mar. 10,1995 & $13.56^{\mathrm{e}, \mathrm{f}}$ & - \\
\hline
\end{tabular}

${ }^{\mathrm{e}} \mathrm{Gage}$ height determined from floodmark.

f Affected by ice.

${ }^{\mathrm{i}}$ Discharge computed from indirect measurement. 


\section{Turkey River at Garber, Iowa}

Location.--Latitude $42^{\circ} 44^{\prime} 24^{\prime \prime}$, longitude $91^{\circ} 15^{\prime} 42^{\prime \prime}$, in SE1/4 NW1/4 sec. 36, T.92 N., R.4 W., Clayton County, Hydrologic Unit 07060004 , on right bank $10 \mathrm{ft}$ upstream from bridge on County Road C43, $800 \mathrm{ft}$ upstream from Wayman Creek, 1,000 ft southeast of Garber, 2,000 ft downstream from Elk Creek, 1 mi downstream from Volga River, and $21.2 \mathrm{mi}$ upstream from mouth.

Drainage area.--1,545 $\mathrm{mi}^{2}$.

Gage.--Water-stage encoder. Datum of gage is $634.46 \mathrm{ft}$ above sea level. Prior to Feb. 7, 1935, nonrecording gage at same site and datum.

Stage-discharge relation.--Defined by current-meter and indirect measurements.

Flood stage.--17 ft.

Remarks.--Base for partial-duration series, $8,000 \mathrm{ft}^{3} / \mathrm{s}$; prior to 1974 , peak base was $10,000 \mathrm{ft}^{3} / \mathrm{s}$.

Peak stages and discharges

[Water year, October 1-September 30; $\mathrm{ft}$, feet above gage datum; $\mathrm{ft}^{3} / \mathrm{s}$, cubic feet per second; --, not determined]

\begin{tabular}{|c|c|c|c|}
\hline Water year & Date & $\begin{array}{c}\text { Gage height } \\
\text { (ft) }\end{array}$ & $\begin{array}{c}\text { Discharge } \\
\left(\mathrm{ft}^{3} / \mathrm{s}\right)\end{array}$ \\
\hline 1902 & May 18,1902 & 23.70 & $25,000^{\mathrm{c}}$ \\
\hline \multicolumn{4}{|c|}{ (Systematic operation of gage began in August 1913) } \\
\hline 1914 & June 15,1914 & 13.2 & 8,960 \\
\hline 1915 & Aug. 4,1915 & 14.7 & 10,900 \\
\hline \multirow[t]{3}{*}{1916} & Mar. 25, 1916 & 20.60 & 18,000 \\
\hline & June 2,1916 & 22.0 & 20,300 \\
\hline & Sept. 30,1916 & 17.79 & 11,900 \\
\hline \multicolumn{4}{|c|}{ (Gage discontinued November 1916, reactivated May 14, 1919) } \\
\hline 1919 & June 4,1919 & 16.8 & 13,100 \\
\hline 1920 & Mar. 12,1920 & 15.1 & 11,000 \\
\hline 1921 & May 31,1921 & 14.5 & 10,400 \\
\hline \multirow[t]{2}{*}{1922} & Feb. 23,1922 & $28.06^{e, j}$ & 32,300 \\
\hline & July 22,1922 & 23.00 & 23,000 \\
\hline \multirow[t]{2}{*}{1923} & Mar. 4,1923 & 17.2 & 13,800 \\
\hline & Apr. $\quad 3,1923$ & 24.2 & 25,200 \\
\hline \multirow[t]{3}{*}{1924} & Mar. 4,1924 & 15.0 & 11,000 \\
\hline & July 21,1924 & 17.4 & 14,600 \\
\hline & Aug. 19,1924 & 15.5 & 11,700 \\
\hline \multirow[t]{3}{*}{1925} & June 15,1925 & 24.7 & 26,200 \\
\hline & June 17,1925 & 15.5 & 11,700 \\
\hline & June 24,1925 & 15.5 & 11,700 \\
\hline 1926 & Aug. 20, 1926 & 12.0 & 7,130 \\
\hline \multirow[t]{2}{*}{1927} & Oct. $\quad 3,1926$ & 16.80 & 13,700 \\
\hline & May 28,1927 & 14.6 & 10,300 \\
\hline \multicolumn{4}{|c|}{ (Gage discontinued September 1927, reactivated April 1929) } \\
\hline 1929 & July 13,1929 & -- & 7,630 \\
\hline 1930 & June 13,1930 & - & $14,500^{c}$ \\
\hline
\end{tabular}




\section{Turkey River at Garber, Iowa}

Peak stages and discharges--Continued

\begin{tabular}{|c|c|c|c|}
\hline Water year & Date & $\begin{array}{l}\text { Gage height } \\
\text { (ft) }\end{array}$ & $\begin{array}{c}\text { Discharge } \\
\left(\mathrm{ft}^{3} / \mathrm{s}\right)\end{array}$ \\
\hline \multicolumn{4}{|c|}{ (Gage discontinued September 1930, reactivated October 1932) } \\
\hline \multirow[t]{6}{*}{1933} & Dec. 24,1932 & 14.9 & 10,700 \\
\hline & Mar. 30,1933 & 22.5 & 20,600 \\
\hline & Apr. $\quad 1,1933$ & 20.9 & 18,500 \\
\hline & Apr. 10,1933 & 14.4 & 10,200 \\
\hline & May 20,1933 & 14.7 & 10,600 \\
\hline & July 2,1933 & 22.4 & 20,400 \\
\hline 1934 & Jan. 22,1934 & 11.5 & 6,230 \\
\hline 1935 & Mar. 4,1935 & 19.9 & 17,100 \\
\hline 1936 & Mar. 11, 1936 & $20.7^{f}$ & $15,000^{c}$ \\
\hline \multirow[t]{2}{*}{1937} & Mar. $\quad 6,1937$ & 20.8 & 18,900 \\
\hline & June 13,1937 & 17.1 & 13,500 \\
\hline 1938 & Sept. 13,1938 & 21.1 & 19,600 \\
\hline 1939 & Mar. 14, 1939 & $19.13^{f}$ & $9,200^{c}$ \\
\hline \multirow[t]{2}{*}{1940} & July 27,1940 & 25.3 & 26,100 \\
\hline & Aug. 27, 1940 & 16.4 & 10,400 \\
\hline \multirow[t]{4}{*}{1941} & Mar. 21, 1941 & 17.6 & 12,300 \\
\hline & May 28,1941 & 20.0 & 16,200 \\
\hline & May 31,1941 & 20.0 & 16,200 \\
\hline & June 12,1941 & 23.3 & 22,100 \\
\hline 1942 & June 30,1942 & 17.5 & 12,000 \\
\hline \multirow[t]{2}{*}{1943} & Mar. 16,1943 & 21.0 & 17,600 \\
\hline & Aug. 13,1943 & 20.0 & 15,900 \\
\hline \multirow[t]{2}{*}{1944} & May 23,1944 & 16.6 & 10,800 \\
\hline & June 16,1944 & 20.6 & 16,900 \\
\hline \multirow[t]{4}{*}{1945} & Mar. 18,1945 & 17.2 & 11,600 \\
\hline & June 2,1945 & 18.2 & 13,000 \\
\hline & June 28,1945 & 17.3 & 11,700 \\
\hline & Aug. 14,1945 & 17.0 & 11,300 \\
\hline \multirow[t]{3}{*}{1946} & Jan. $\quad 5,1946$ & 24.3 & 24,100 \\
\hline & Mar. 6,1946 & 22.1 & 19,600 \\
\hline & Mar. 13, 1946 & 17.9 & 12,600 \\
\hline \multirow[t]{4}{*}{1947} & Mar. 13, 1947 & 17.2 & 11,600 \\
\hline & Apr. 10,1947 & 17.3 & 11,700 \\
\hline & June 13,1947 & 26.6 & 29,000 \\
\hline & June 29,1947 & 22.9 & 21,200 \\
\hline \multirow[t]{5}{*}{1948} & Feb. 28,1948 & $23.62^{f}$ & $18,000^{c}$ \\
\hline & Mar. 15,1948 & 17.1 & 11,400 \\
\hline & Mar. 17,1948 & 19.8 & 15,600 \\
\hline & Mar. 19,1948 & 21.7 & 19,000 \\
\hline & May 10,1948 & 17.3 & 11,700 \\
\hline 1949 & Mar. $\quad 4,1949$ & 20.5 & 16,800 \\
\hline
\end{tabular}




\section{Turkey River at Garber, Iowa}

Peak stages and discharges--Continued

\begin{tabular}{|c|c|c|c|}
\hline Water year & Date & $\begin{array}{c}\text { Gage height } \\
\text { (ft) }\end{array}$ & $\begin{array}{c}\text { Discharge } \\
\left(\mathrm{ft}^{3} / \mathrm{s}\right)\end{array}$ \\
\hline \multirow[t]{7}{*}{1950} & Mar. 7,1950 & 23.7 & 23,700 \\
\hline & Mar. 27, 1950 & 23.3 & 22,900 \\
\hline & June 13,1950 & 16.9 & 11,900 \\
\hline & June 25,1950 & 17.0 & 12,000 \\
\hline & July 16,1950 & 17.2 & 12,300 \\
\hline & Aug. $\quad 1,1950$ & 17.3 & 12,400 \\
\hline & Sept. 22,1950 & 17.9 & 13,200 \\
\hline \multirow[t]{7}{*}{1951} & Feb. 26,1951 & 18.72 & 14,600 \\
\hline & Mar. 28, 1951 & 22.79 & 21,900 \\
\hline & Apr. 7,1951 & 20.90 & 18,300 \\
\hline & Apr. 26,1951 & 15.94 & 10,500 \\
\hline & Apr. 30,1951 & 20.44 & 17,400 \\
\hline & June 27,1951 & 16.71 & 11,600 \\
\hline & July $\quad 8,1951$ & 21.44 & 19,200 \\
\hline 1952 & Apr. $\quad 1,1952$ & 15.88 & 9,840 \\
\hline \multirow[t]{3}{*}{1953} & July 27,1953 & 20.62 & 16,900 \\
\hline & Aug. 4,1953 & 19.71 & 15,300 \\
\hline & Aug. 6,1953 & 19.85 & 15,700 \\
\hline 1954 & June 21,1954 & 19.94 & 16,400 \\
\hline 1955 & June 3,1955 & 15.32 & 9,840 \\
\hline 1956 & Mar. 28, 1956 & 17.00 & 12,300 \\
\hline 1957 & June 18,1957 & 14.20 & 7,320 \\
\hline 1958 & May 31,1958 & 17.61 & 12,100 \\
\hline \multirow[t]{3}{*}{1959} & Mar. 26, 1959 & 21.06 & 17,000 \\
\hline & Apr. $\quad 1,1959$ & 19.93 & 15,000 \\
\hline & June 26,1959 & 17.35 & 11,400 \\
\hline \multirow[t]{3}{*}{1960} & Jan. 12,1960 & 20.02 & 15,200 \\
\hline & Mar. 30,1960 & 22.96 & 20,000 \\
\hline & May 6,1960 & 21.07 & 17,000 \\
\hline \multirow[t]{5}{*}{1961} & Feb. 23,1961 & 17.31 & 11,200 \\
\hline & Mar. 6,1961 & 16.48 & 10,100 \\
\hline & Mar. 26, 1961 & 22.84 & 19,700 \\
\hline & Aug. $\quad 1,1961$ & 17.55 & 11,600 \\
\hline & Sept. 30,1961 & 17.79 & 11,900 \\
\hline \multirow[t]{3}{*}{1962} & Nov. 2,1962 & 16.80 & 10,500 \\
\hline & Mar. 29, 1962 & 24.70 & 24,500 \\
\hline & May 6,1962 & 17.47 & 11,500 \\
\hline \multirow[t]{2}{*}{1963} & Mar. 17,1963 & 20.69 & 16,300 \\
\hline & Mar. 19, 1963 & 16.79 & 10,500 \\
\hline 1964 & Apr. 3,1964 & 17.00 & 10,800 \\
\hline \multirow[t]{2}{*}{1965} & 1,1965 & $22.10^{f}$ & $13,000^{c}$ \\
\hline & Apr. 1,1965 & 19.15 & 13,800 \\
\hline \multirow[t]{2}{*}{1966} & Feb. $\quad 9,1966$ & 24.80 & 24,800 \\
\hline & July 14,1966 & 20.98 & 16,100 \\
\hline
\end{tabular}




\section{Turkey River at Garber, Iowa}

Peak stages and discharges--Continued

\begin{tabular}{|c|c|c|c|}
\hline Water year & Date & $\begin{array}{c}\text { Gage height } \\
\text { (ft) }\end{array}$ & $\begin{array}{c}\text { Discharge } \\
\left(\mathrm{ft}^{3} / \mathrm{s}\right)\end{array}$ \\
\hline 1967 & Jan. 24,1967 & 22.18 & 18,900 \\
\hline \multirow[t]{3}{*}{1968} & July 17,1968 & 16.83 & 10,300 \\
\hline & Aug. 8,1968 & 17.02 & 10,500 \\
\hline & Sept. 22, 1968 & 16.91 & 10,400 \\
\hline 1969 & June 29,1969 & 22.50 & 19,600 \\
\hline 1970 & Aug. 8,1970 & 17.32 & 11,200 \\
\hline \multirow[t]{4}{*}{1971} & Mar. 15,1971 & 19.02 & 13,600 \\
\hline & Apr. $\quad 1,1971$ & 18.39 & 12,700 \\
\hline & June 20,1971 & 20.81 & 16,500 \\
\hline & July 13,1971 & 19.05 & 13,700 \\
\hline \multirow[t]{3}{*}{1972} & Sept. 11,1972 & 17.64 & 10,300 \\
\hline & Sept. 13,1972 & 17.42 & 10,000 \\
\hline & Sept. 28,1972 & 21.41 & 16,300 \\
\hline \multirow[t]{4}{*}{1973} & Jan. 18,1973 & $21.90^{f}$ & $15,000^{c}$ \\
\hline & Feb. $\quad 2,1973$ & 19.00 & 12,300 \\
\hline & Apr. 16,1973 & 22.88 & 19,600 \\
\hline & May 8,1973 & 19.17 & 12,500 \\
\hline \multirow[t]{3}{*}{1974} & Mar. 3, 1974 & 16.40 & 8,680 \\
\hline & June 10,1974 & 16.80 & 9,160 \\
\hline & June 21,1974 & 21.08 & 15,700 \\
\hline \multirow[t]{3}{*}{1975} & Mar. 22,1975 & 21.72 & 16,500 \\
\hline & Mar. 24,1975 & 20.93 & 16,700 \\
\hline & Apr. 29,1975 & 16.45 & 9,740 \\
\hline \multirow[t]{2}{*}{1976} & Mar. 12,1976 & 22.18 & 18,300 \\
\hline & Apr. 22,1976 & 15.68 & 8,220 \\
\hline 1977 & Aug. 16, 1977 & 15.52 & 8,320 \\
\hline \multirow[t]{2}{*}{1978} & Apr. $\quad 6,1978$ & 15.43 & 8,220 \\
\hline & May 13,1978 & 15.46 & 8,250 \\
\hline \multirow[t]{6}{*}{1979} & Mar. 19,1979 & 25.59 & 26,000 \\
\hline & Mar. 24, 1979 & 17.00 & 10,300 \\
\hline & Mar. 30,1979 & 20.70 & 16,300 \\
\hline & May 3,1979 & 15.40 & 8,180 \\
\hline & Aug. 18,1979 & 21.17 & 17,100 \\
\hline & Aug. 24,1979 & 15.99 & 8,890 \\
\hline \multirow[t]{3}{*}{1980} & Jan. 16,1980 & $17.77^{\mathrm{f}}$ & $11,000^{c}$ \\
\hline & Mar. 16,1980 & $18.79^{f}$ & $10,800^{c}$ \\
\hline & Aug. 21,1980 & 15.86 & 8,730 \\
\hline \multirow[t]{2}{*}{1981} & Aug. $\quad 2,1981$ & 23.29 & 20,500 \\
\hline & Sept. 1,1981 & 20.28 & 14,400 \\
\hline \multirow[t]{3}{*}{1982} & Mar. 14, 1982 & 16.25 & 8,800 \\
\hline & Mar. 16, 1982 & 20.65 & 15,500 \\
\hline & Mar. 20,1982 & 17.15 & 9,920 \\
\hline
\end{tabular}


05412500 Turkey River at Garber, Iowa

Peak stages and discharges--Continued

\begin{tabular}{|c|c|c|c|}
\hline Water year & Date & $\begin{array}{c}\text { Gage height } \\
\text { (ft) }\end{array}$ & $\begin{array}{c}\text { Discharge } \\
\left(\mathrm{ft}^{3} / \mathrm{s}\right)\end{array}$ \\
\hline \multirow[t]{8}{*}{1983} & Nov. 12,1982 & 19.37 & 13,300 \\
\hline & Dec. 6,1982 & 15.88 & 8,190 \\
\hline & Dec. 29,1982 & 16.37 & 8,600 \\
\hline & Feb. 22,1983 & 18.33 & 11,300 \\
\hline & Apr. 15,1983 & 16.72 & 9,290 \\
\hline & May 20,1983 & 16.06 & 8,430 \\
\hline & May 23,1983 & 16.63 & 9,140 \\
\hline & July $\quad 2,1983$ & 17.25 & 10,100 \\
\hline \multirow[t]{2}{*}{1984} & Feb. 19,1984 & 17.62 & 10,100 \\
\hline & Apr. 30,1984 & 18.50 & 11,400 \\
\hline \multirow[t]{2}{*}{1985} & Feb. 24,1985 & 19.11 & 12,300 \\
\hline & Mar. 9,1985 & 17.13 & 9,390 \\
\hline \multirow[t]{3}{*}{1986} & Mar. 19,1986 & 22.47 & 19,400 \\
\hline & June 22,1986 & 16.13 & 8,290 \\
\hline & Sept. 21,1986 & 16.50 & 8,900 \\
\hline 1987 & Oct. 14,1986 & 15.37 & 7,390 \\
\hline 1988 & Mar. 9,1988 & $12.83^{\mathrm{f}}$ & 3,400 \\
\hline 1989 & Mar. 12, 1989 & $17.82^{\mathrm{f}}$ & 9,900 \\
\hline 1990 & Aug. 27, 1990 & 24.63 & 23,000 \\
\hline \multirow[t]{3}{*}{1991} & Apr. 13,1991 & 20.63 & 15,700 \\
\hline & Apr. 30,1991 & 17.46 & 9,940 \\
\hline & June 15,1991 & $30.10^{\mathrm{e}}$ & $49,900^{\mathrm{i}}$ \\
\hline 1992 & Apr. 21,1992 & 18.17 & 11,400 \\
\hline \multirow[t]{12}{*}{1993} & Mar. 27, 1993 & 18.62 & 11,800 \\
\hline & Mar. 31,1993 & 22.94 & 19,400 \\
\hline & Apr. 21,1993 & 18.24 & 10,800 \\
\hline & May 2,1993 & 18.16 & 10,700 \\
\hline & June 21,1993 & 19.58 & 13,000 \\
\hline & June 30,1993 & 16.46 & 8,470 \\
\hline & July $\quad 9,1993$ & 19.35 & 12,600 \\
\hline & July 11,1993 & 22.04 & 17,700 \\
\hline & July 19,1993 & 18.05 & 10,500 \\
\hline & Aug. 18, 1993 & 22.71 & 19,100 \\
\hline & Aug. 20, 1993 & 18.46 & 11,100 \\
\hline & Aug. 24, 1993 & 17.61 & 9,920 \\
\hline \multirow[t]{2}{*}{1994} & Feb. 20,1994 & $18.48^{\mathrm{f}}$ & -- \\
\hline & June 23,1994 & 16.98 & 9,700 \\
\hline 1995 & Apr. 13,1995 & 13.35 & 5,230 \\
\hline
\end{tabular}

${ }^{c}$ Approximate.

${ }^{\mathrm{e}} \mathrm{Gage}$ height determined from floodmark.

${ }^{f}$ Affected by ice.

${ }^{\mathrm{i} D}$ Discharge computed from indirect measurement.

$\mathrm{j}_{\text {Maximum gage height known since } 1890 .}$ 
32 


\section{APPENDIX B}

\section{WATER-SURFACE-ELEVATION PROFILES FOR THE TURKEY RIVER BASIN, NORTHEAST IOWA}


34 


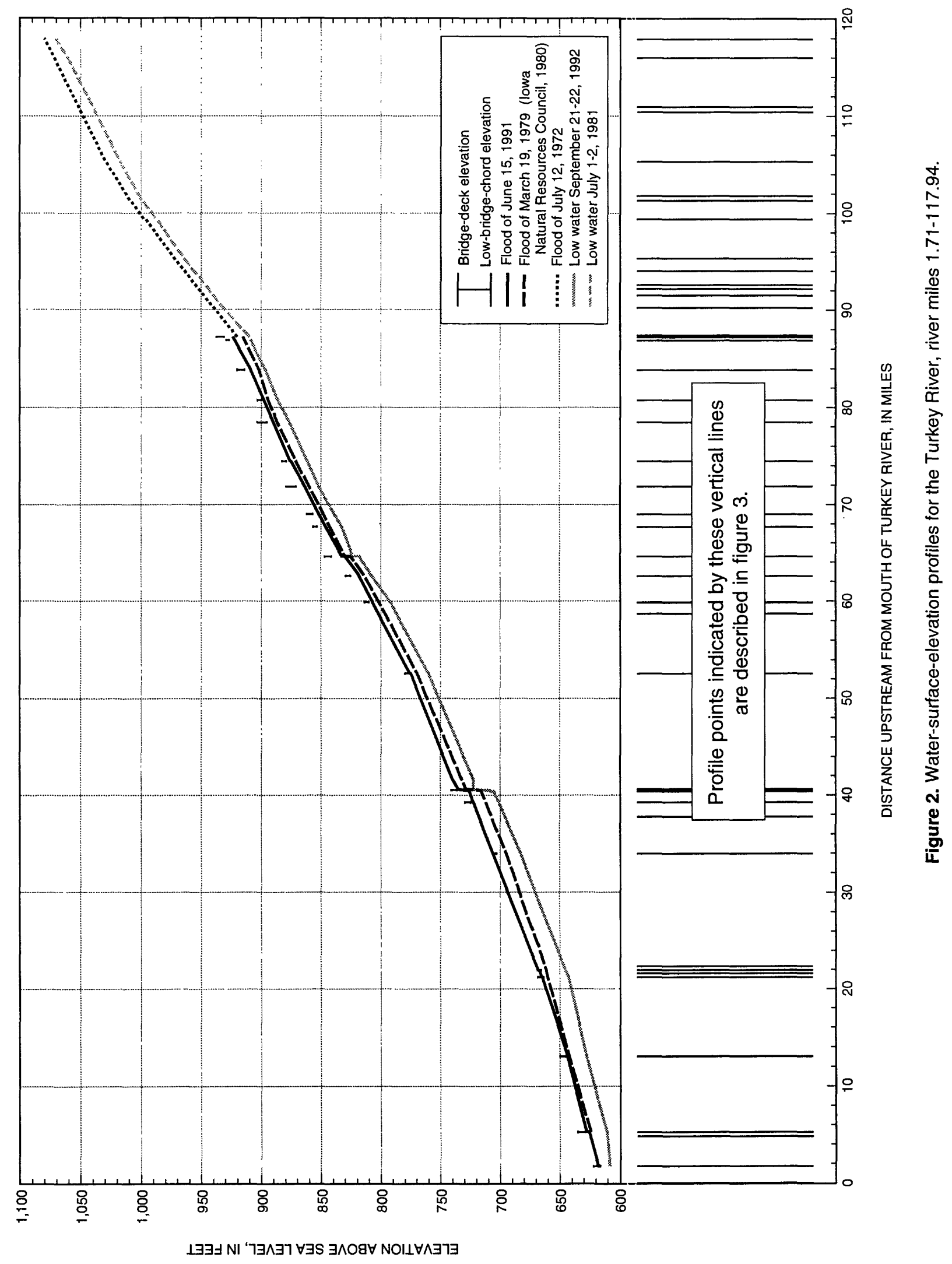




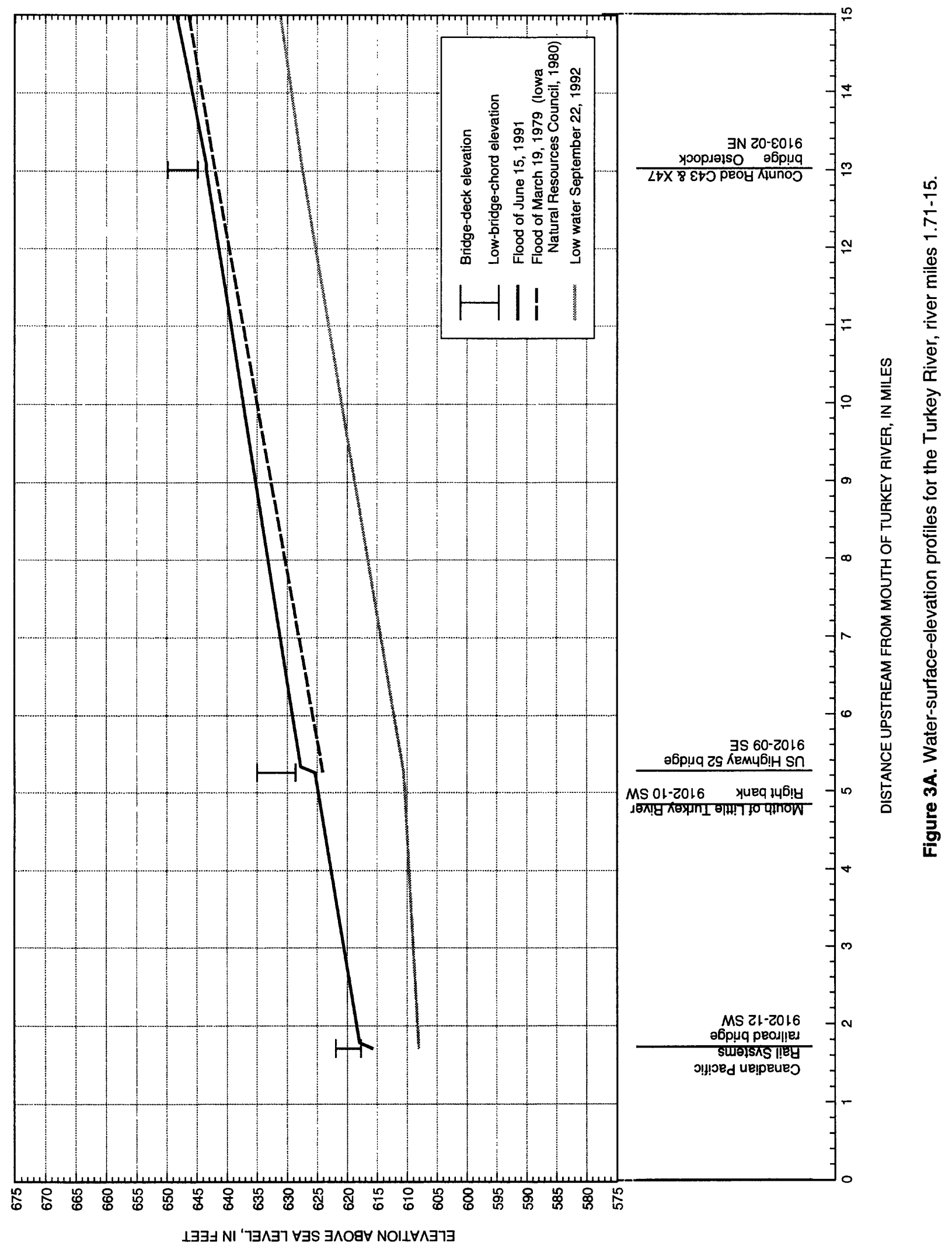




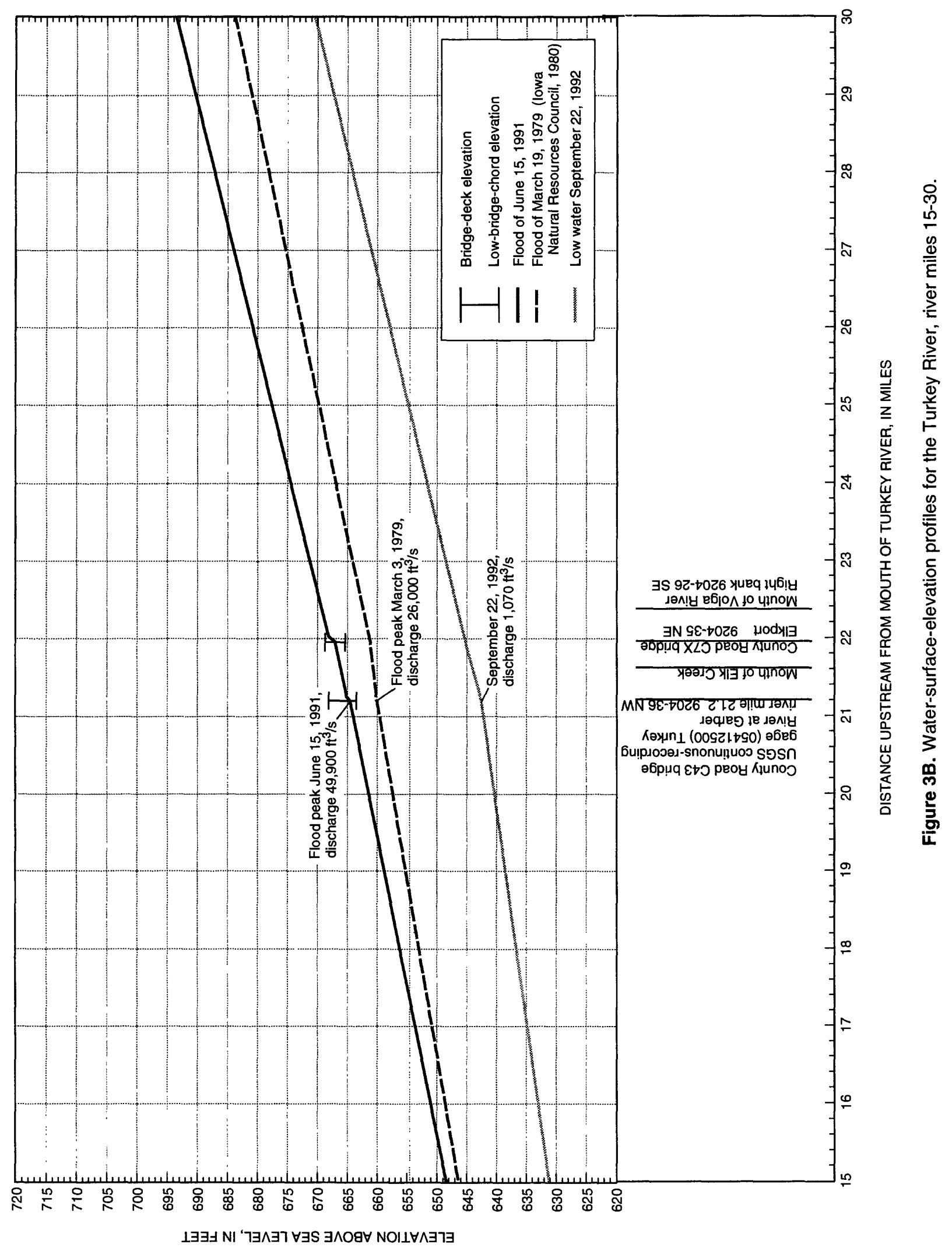




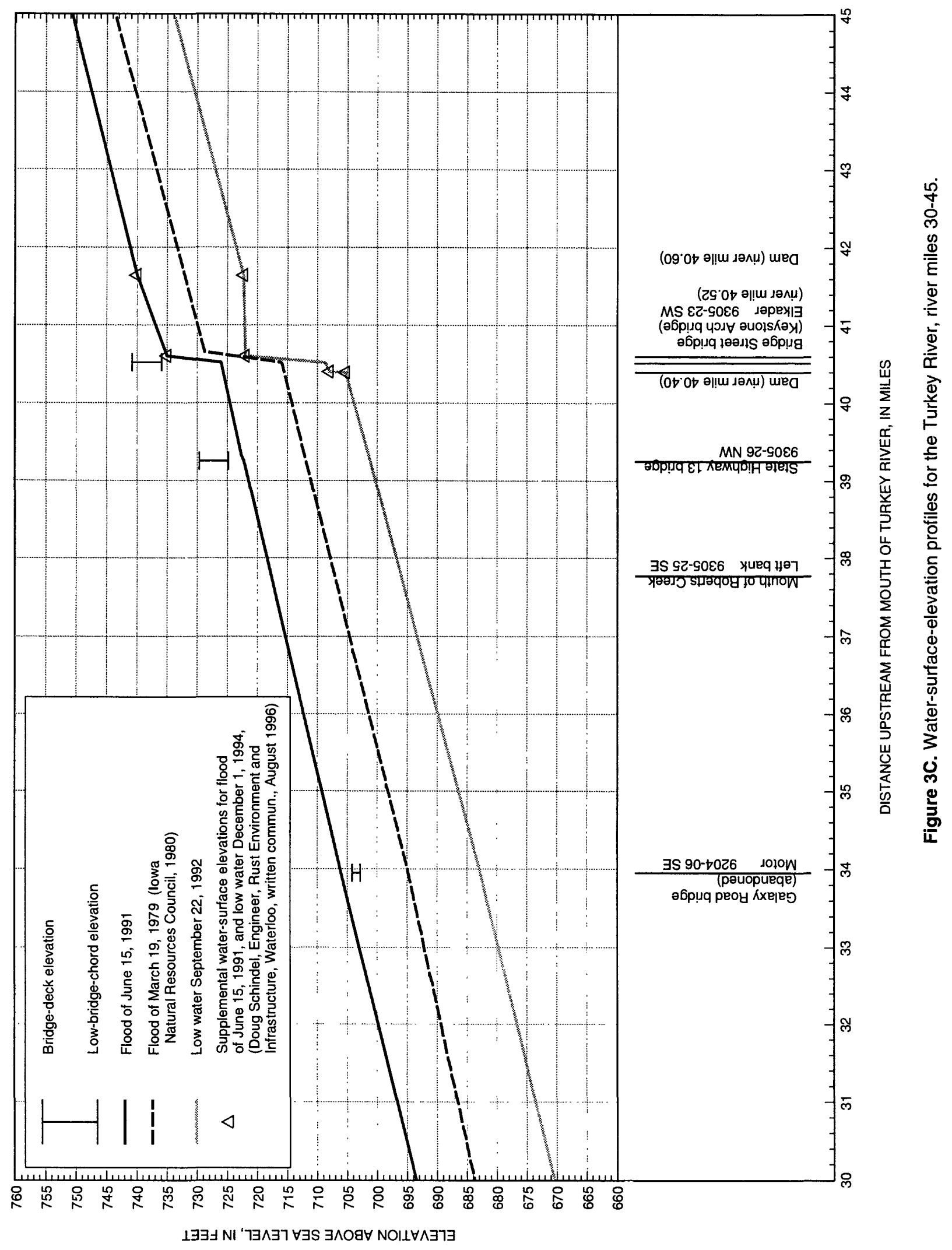




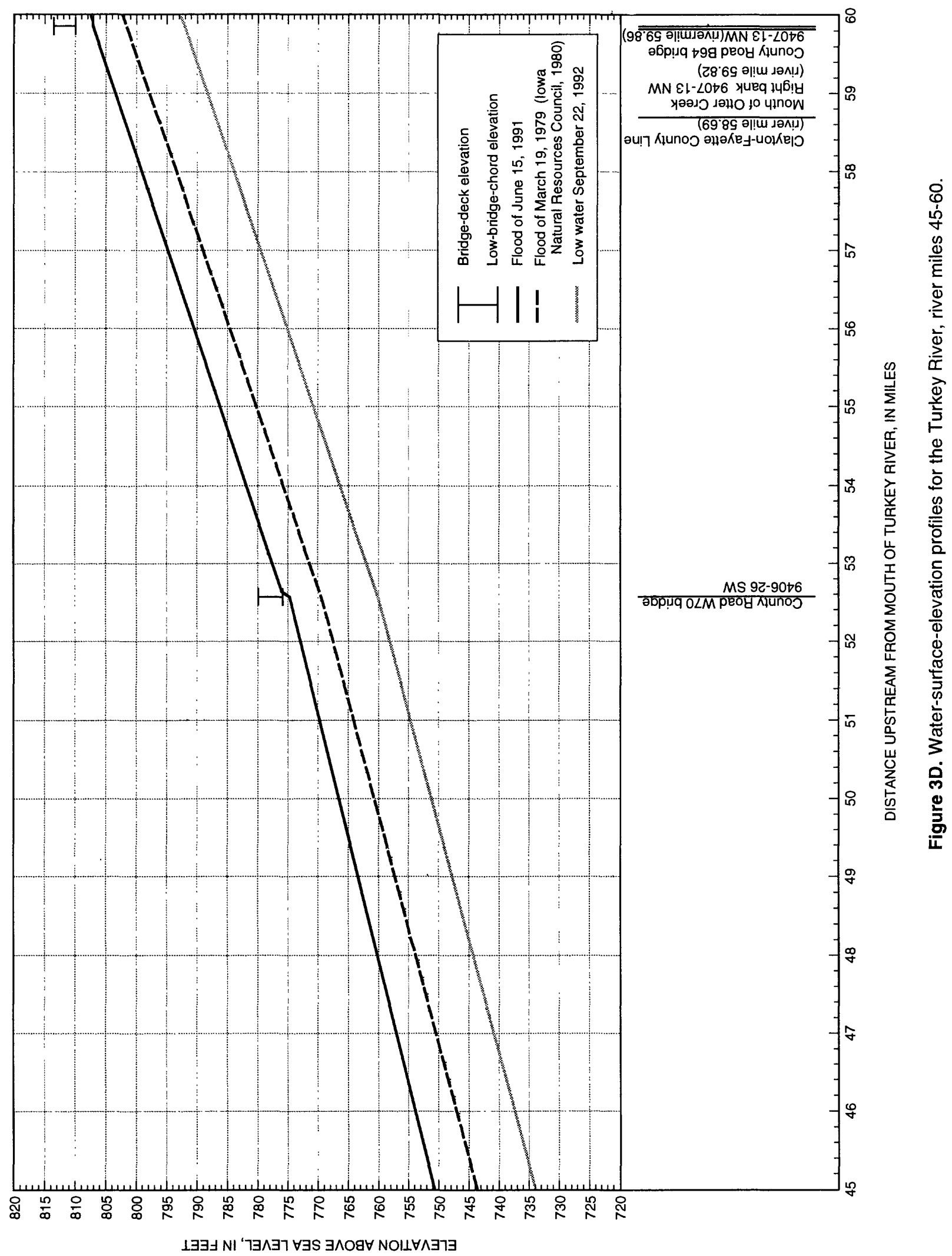




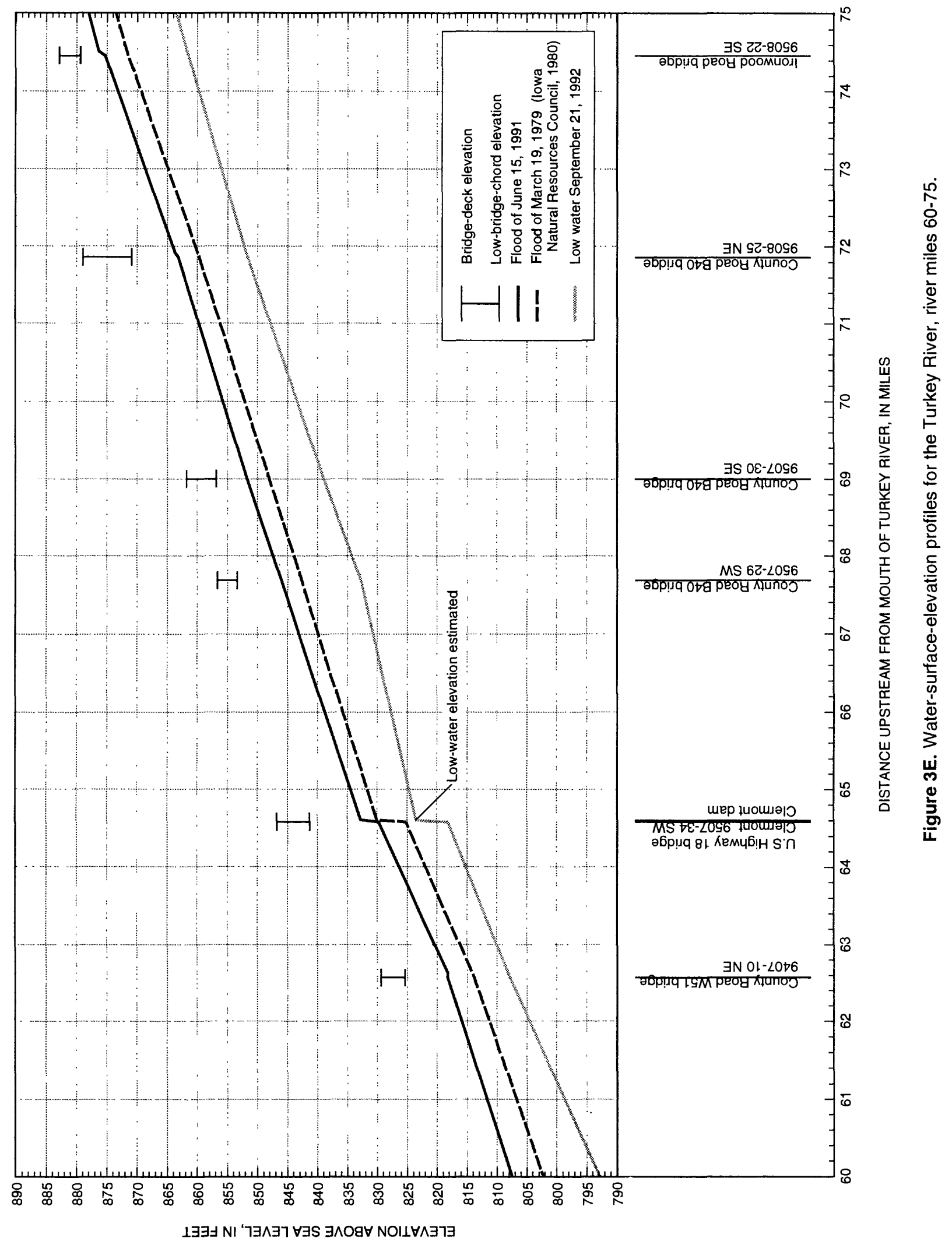




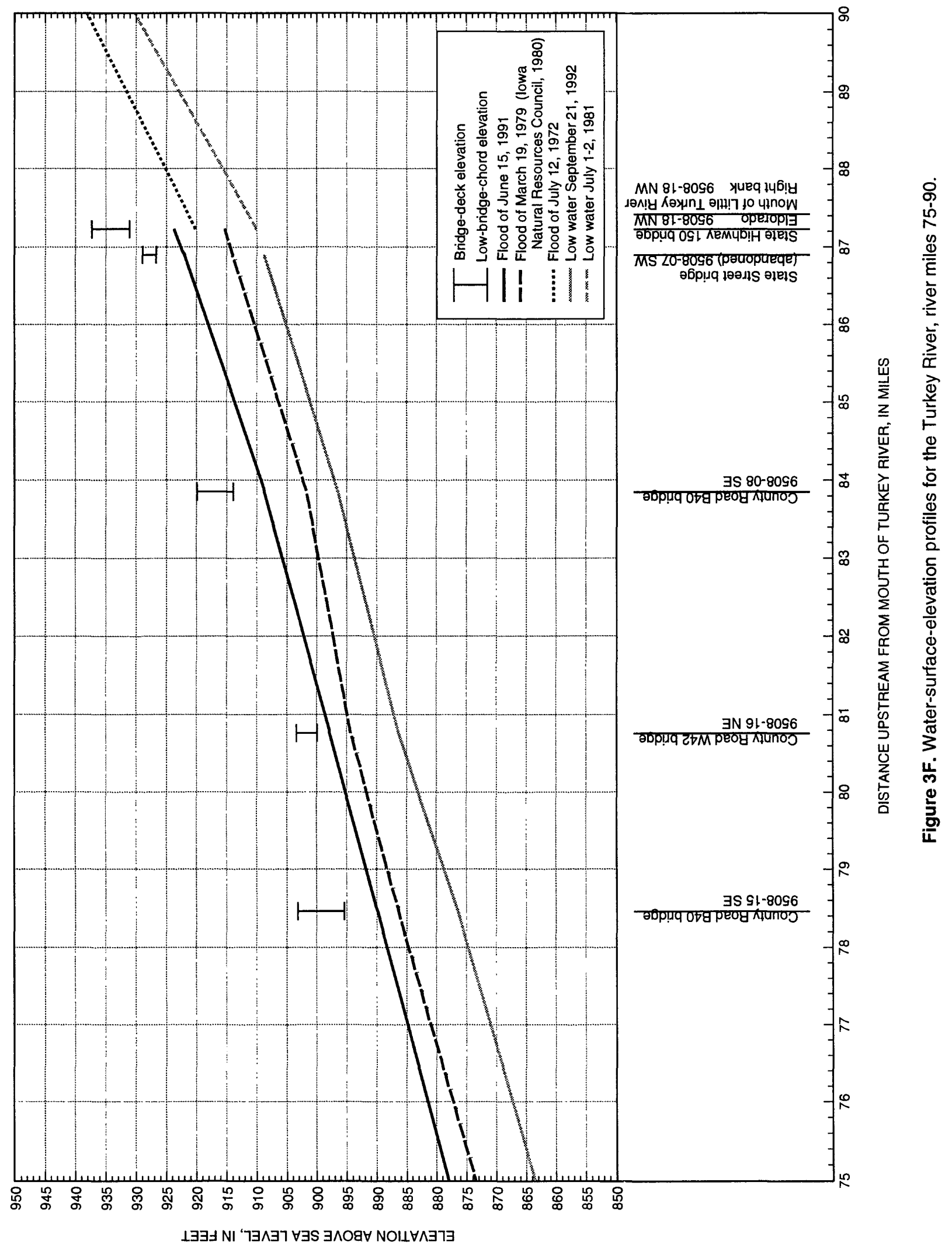




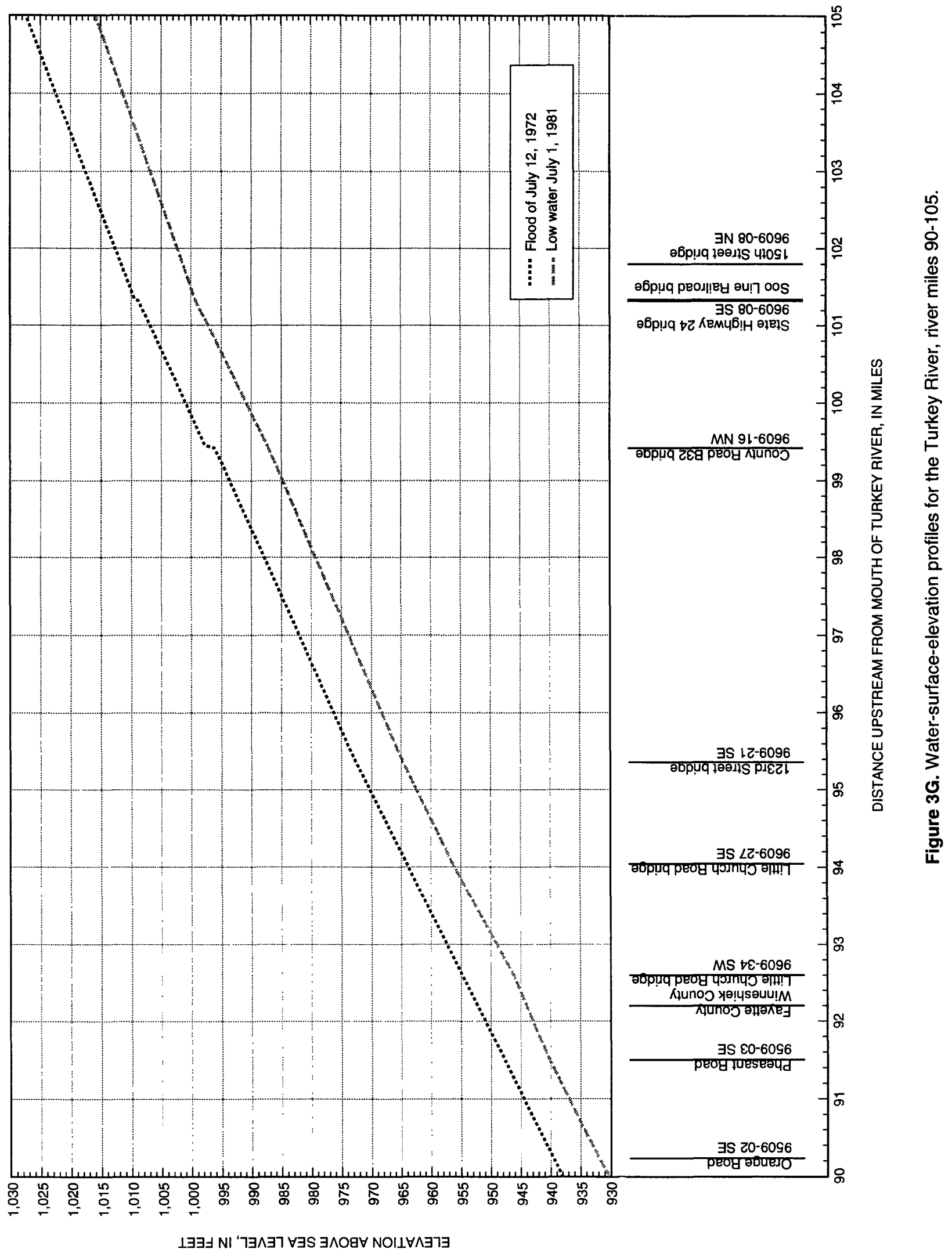




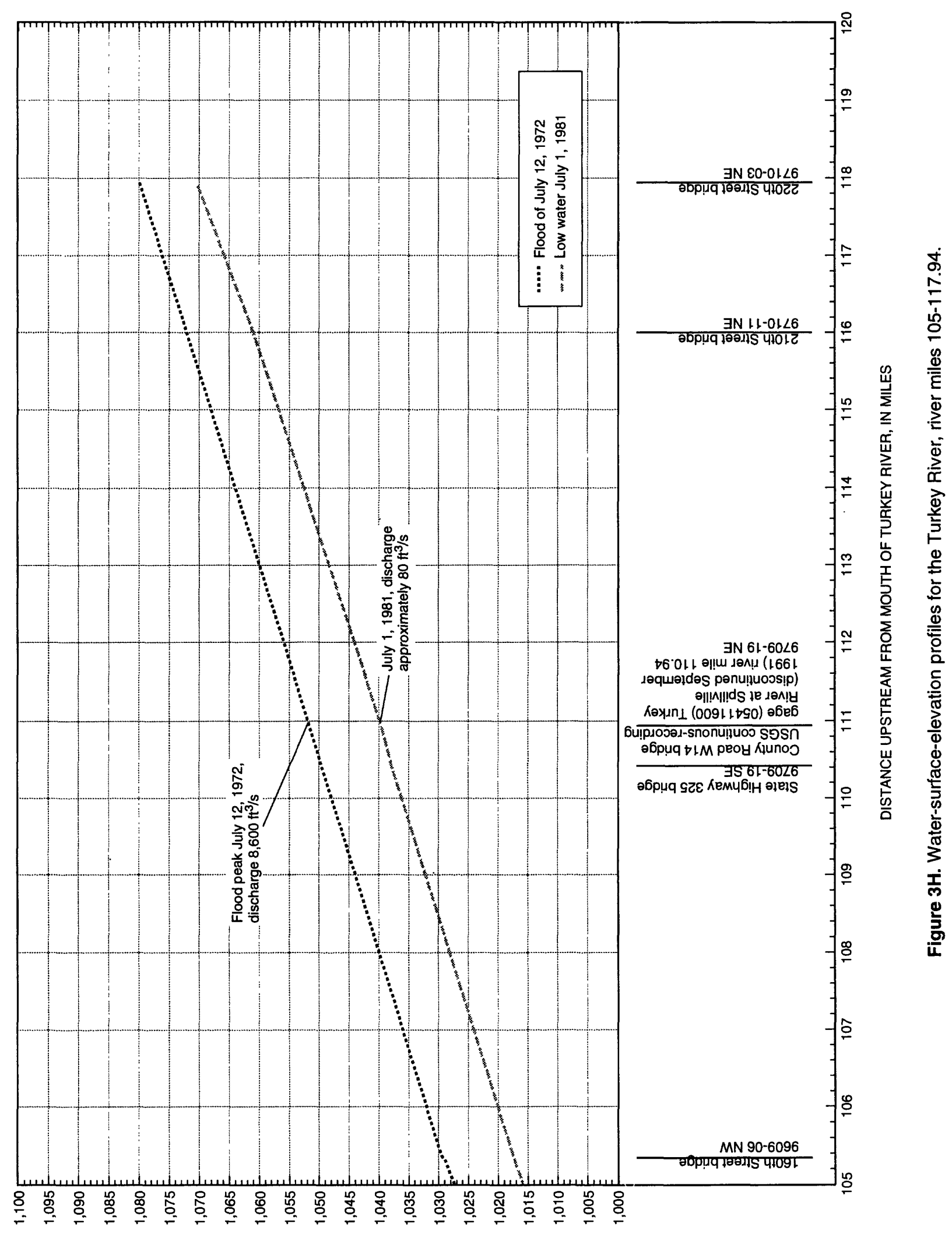

1 $\exists \exists \exists ~ N I ~ ‘ ㅋ \wedge \exists า ~ \forall \exists S ~ \exists \wedge 08 \forall ~ N O I \perp \forall \wedge \exists า \exists$ 


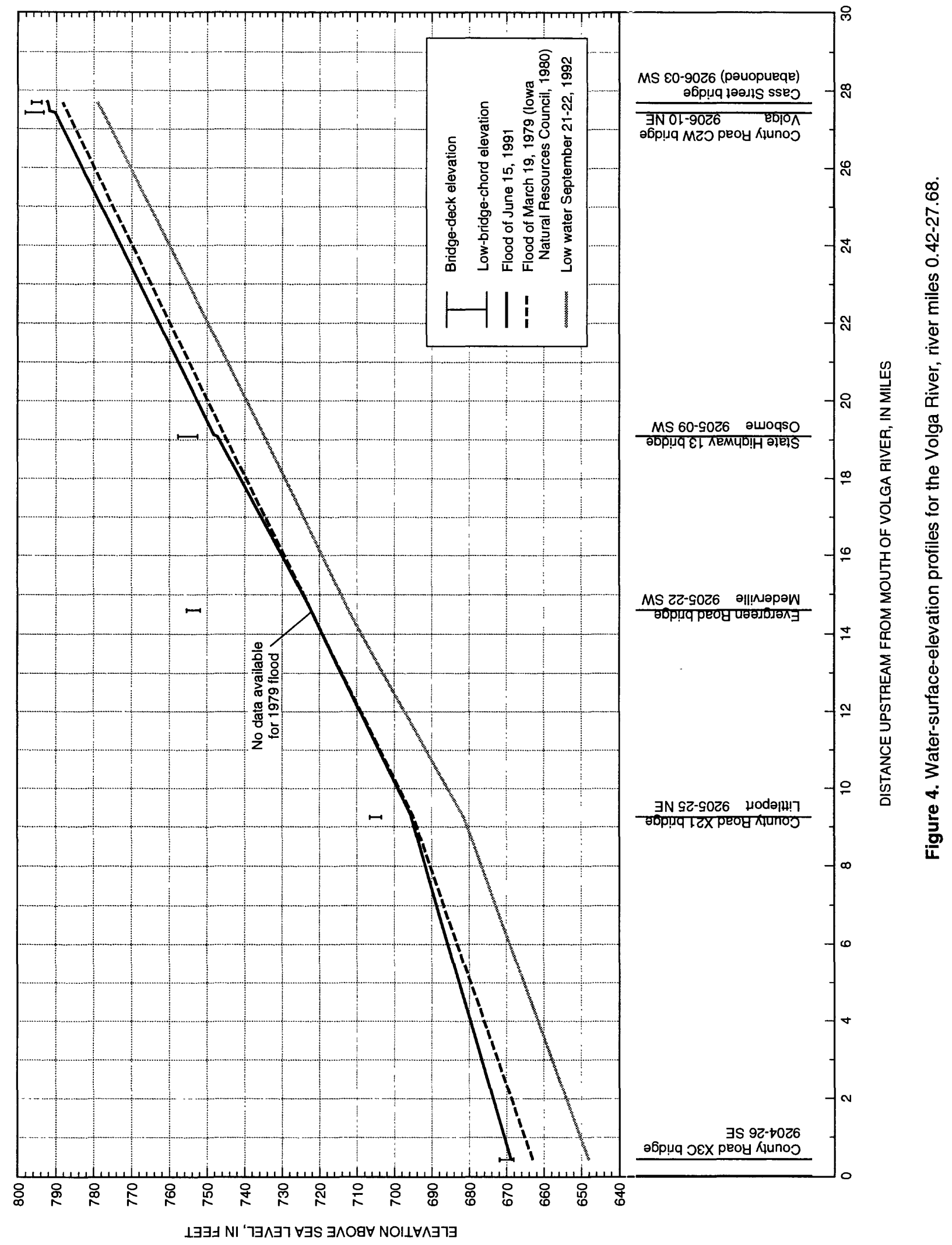




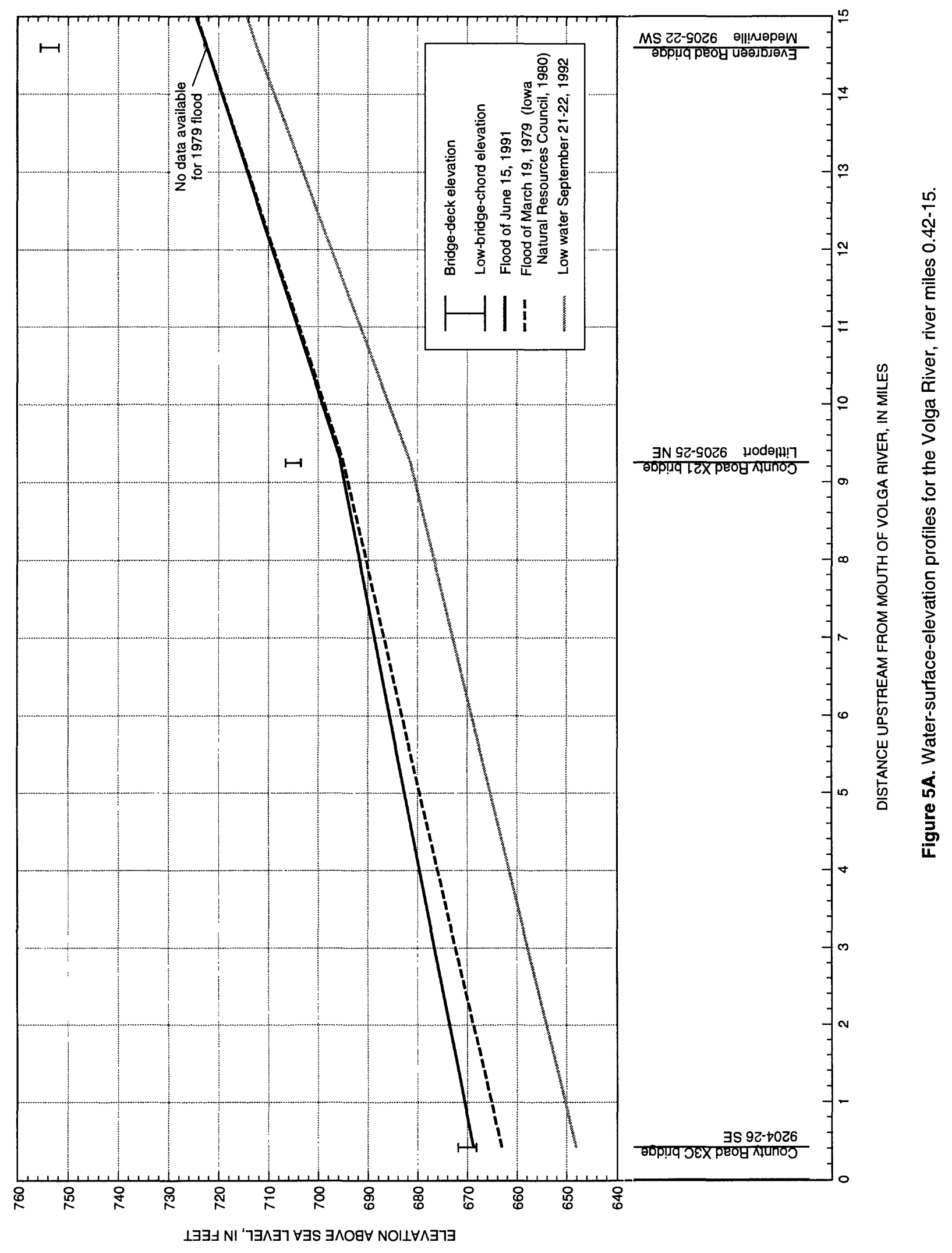




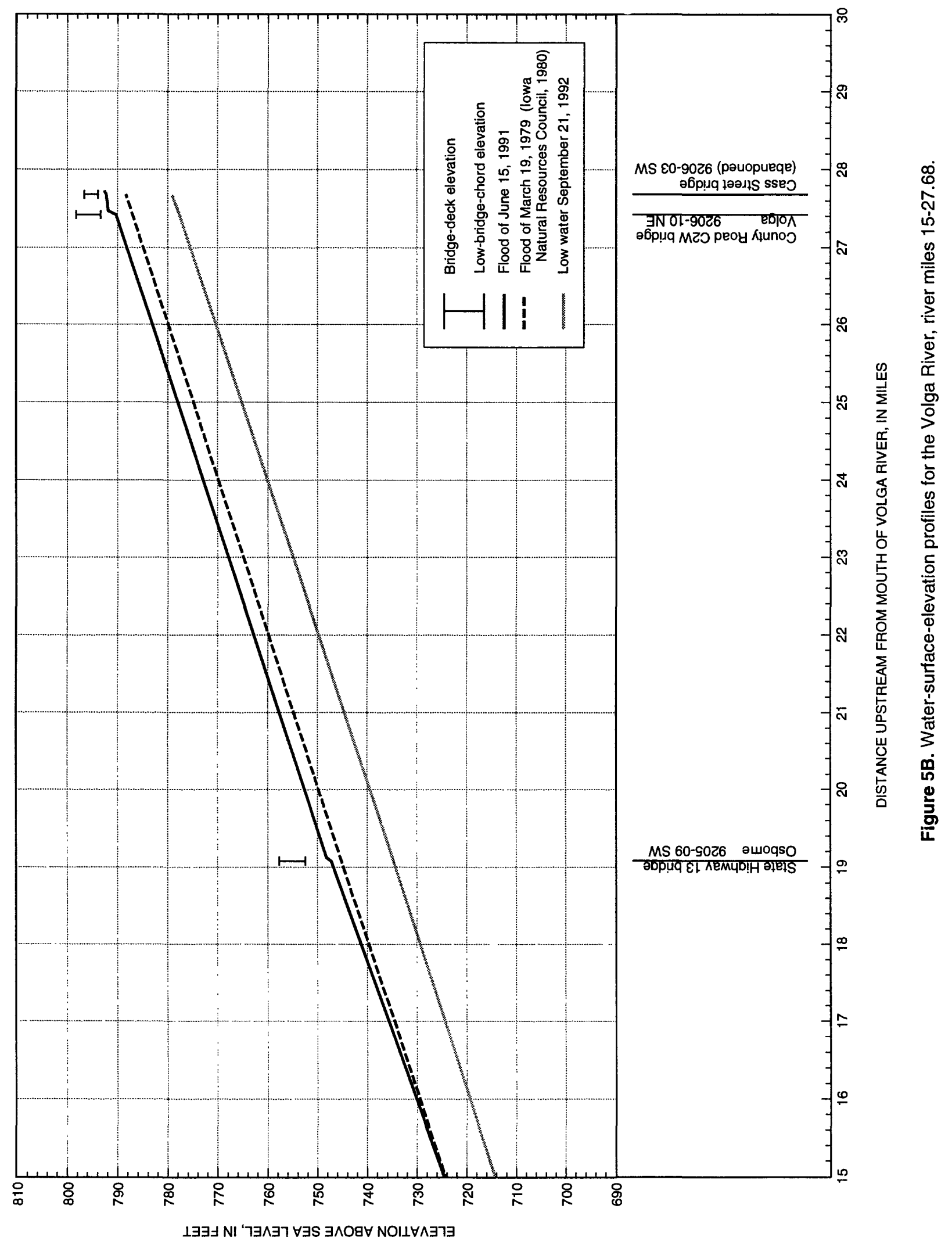




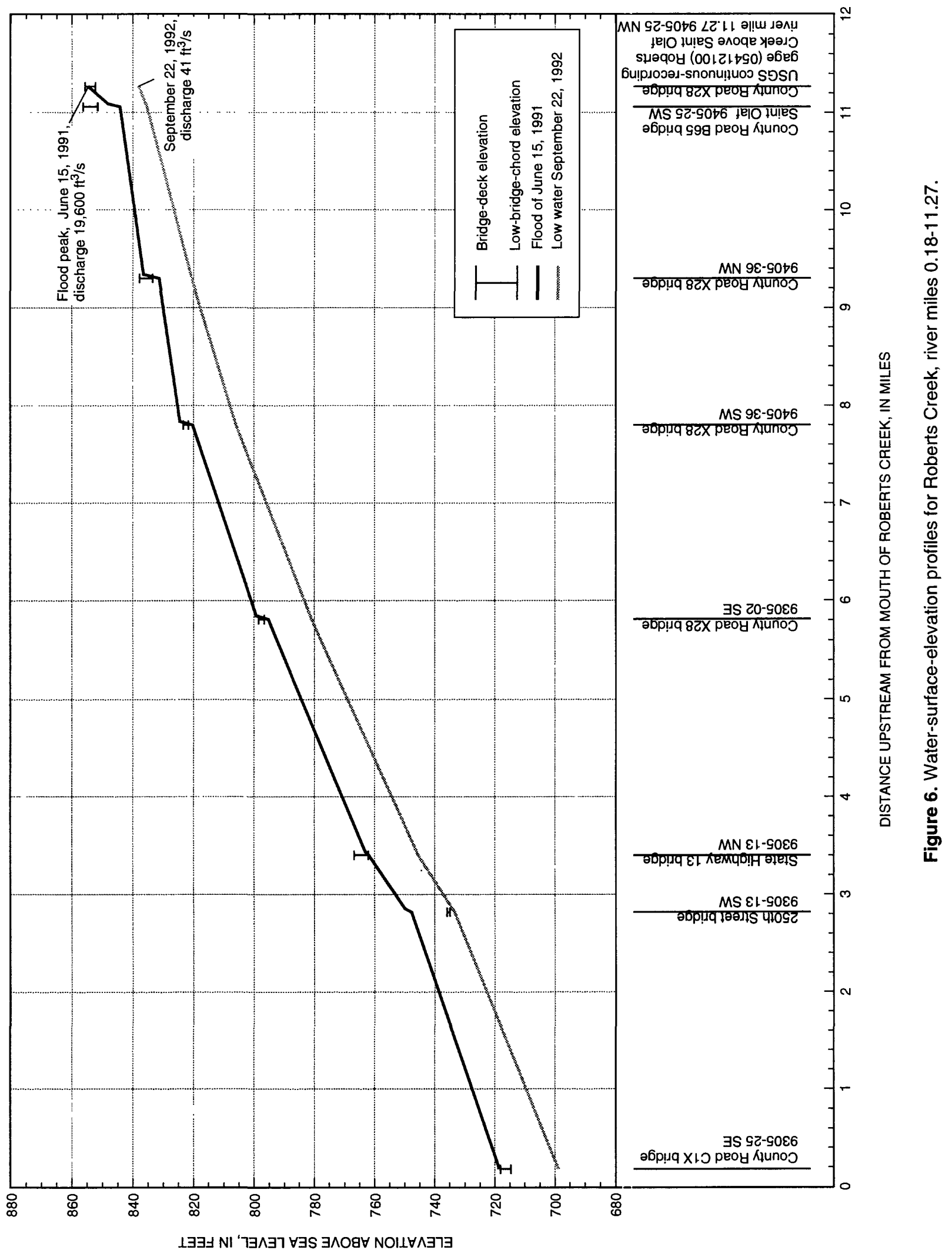




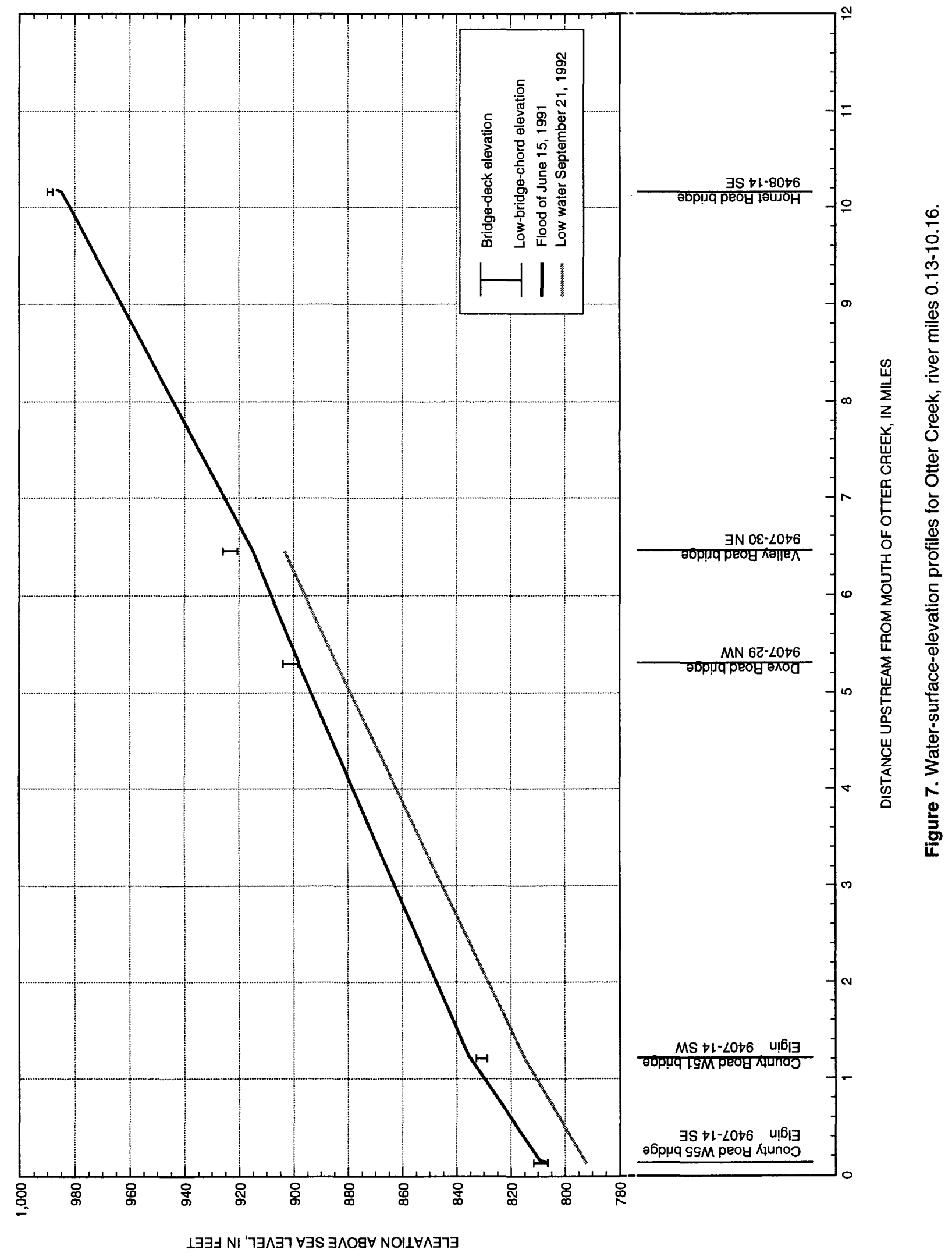




\section{APPENDIX C}

\section{TEMPORARY BENCH MARKS AND REFERENCE POINTS IN THE TURKEY RIVER BASIN, NORTHEAST IOWA}

The temporary bench marks (BM) and reference points (RP) listed in this tabulation were established during 1981, 1992, and 1996 by the U.S. Geological Survey (USGS) except those for which credit is given in the descriptions. The work was done as a part of a stream-profile study jointly funded by the Iowa Highway Research Board and the Project Development Division of the Iowa Department of Transportation, and the USGS.

$\mathrm{BM}$ and RP elevations listed in this tabulation were determined from differential leveling that was performed along the following four river reaches that were profiled for the flood of June 15, 1991: Turkey River from the Canadian Pacific Rail Systems railroad bridge, located approximately 2.4 mi east of Millville in Clayton County, to the State Highway 150 bridge in Eldorado in Fayette County (figs. 1-3); Volga River in Clayton County from the County Road X21 bridge in Littleport to the County Road C2W bridge in Volga (figs. 1 and 4-5); Roberts Creek in Clayton County from the County Road C1X bridge, located approximately $1.6 \mathrm{mi}$ southeast of Elkader to the County Road X28 bridge in Saint Olaf (figs. 1 and 6); and Otter Creek in Fayette County from the County Road W55 bridge in Elgin to the Valley Road bridge, located approximately $0.5 \mathrm{mi}$ west of Brainard (figs. 1 and 7). BMs and RPs were set at the majority of bridges crossing the four profiled river reaches in the Turkey River Basin. Level lines to establish the third-order accuracy of the BMs and RPs shown herein were surveyed from bench marks established and adjusted by the National Mapping Division of the USGS, the National Geodetic Survey, or Clayton County. Errors of closure in the USGS level work were adjusted along the level lines to balance the BM and RP elevations. All elevations are referenced to sea level.

The BMs and RPs are identified by an index number, which is composed of the township, range, and section num- ber, and the quarter section in which the BM or RP is located. The township and range numbers are combined into a fourdigit number, such as 9102 for Township 91 North and Range 02 West. The township and range number is followed by a dash and the section number in which the BM or RP is located. Within the section, the quarter in which the BM or RP is located is designated by NE, SE, SW, and NW. A number in parentheses following this letter designation indicates the number of the BM or RP in that particular quarter section. The index number serves to describe the landline location of the $\mathrm{BM}$ or RP without further reference in the body of the description.

Standard BMs and RPs such as chiseled squares, arrows, or crosses on concrete; filed arrows or marks on steel; or existing bolts on bridges were used. Existing marks were used wherever available, and the agency responsible for the mark, when known, is indicated in the description. RPs are distinguished from BMs in this tabulation by the notation "(REFERENCE POINT)" following the index number. RPs were established to permit water-surface elevations to be determined by use of a tape and weight. The terms "right" and "left" in the descriptions are determined as viewed while facing in the direction of the flow of the stream.

The user of this information is cautioned that the BMs and RPs listed herein might have been disturbed, destroyed, or moved since surveys used in this report were made. Many of the BMs and RPs are located on bridges that might have been repaired, replaced, or destroyed since the original level lines were surveyed. It is the responsibility of the user to determine the condition and the suitability of the BM or RP.

Additional information can be obtained by writing to the following address: U.S. Geological Survey, Water Resources Division, Room 269, Federal Building, 400 South Clinton Street, Iowa City, IA 52244. 


\section{TEMPORARY BENCH MARKS AND REFERERNCE POINTS IN THE TURKEY RIVER BASIN, NORTHEAST IOWA}

9102-09 SE (1)--At north of Millville, on U.S. Highway 52 bridge over Turkey River, on right upstream wingwall; National Geodetic Survey (U.S. Coast \& Geodetic Survey) bench mark disk stamped "B179-1970." Elevation obtained from National Geodetic Survey.

Elevation $634.822 \mathrm{ft}$.

9102-09 SE (2)--(REFERENCE POINT) At north of Millville, on U.S. Highway 52 bridge over Turkey River, on downstream curb between 13th and 14th guardrail posts from right end of bridge; chiseled square.

Elevation $634.78 \mathrm{ft}$.

9102-12 SW (1)--Approximately $2.4 \mathrm{mi}$ east of Millville at Canadian Pacific Rail Systems railroad bridge over Turkey River, on right upstream bridge footing, $5.1 \mathrm{ft}$ lower than wood plank, most streamward and downstream bolt; top of bolt.

Elevation $616.89 \mathrm{ft}$.

9102-12 SW (2)--(REFERENCE POINT) Approximately 2.4 mi east of Millville at Canadian Pacific Rail Systems railroad bridge over Turkey River, on third truss member from right upstream bridge abutment, 6 in. lower than wood deck; chiseled arrow.

Elevation $621.43 \mathrm{ft}$.

9103-02 NE (1)--At Osterdock, on County Roads C43 and X47 bridge over Turkey River, on right upstream concrete curb; brass tablet stamped "1957." Elevation obtained from Clayton County Engineer.

Elevation $649.53 \mathrm{ft}$.

9103-02 NE (2)--(REFERENCE POINT) At Osterdock, on County Roads C43 and X47 bridge over Turkey River, on downstream curb between 31 st and 32 nd guardrail posts from left end of bridge; chiseled arrow.

Elevation $650.47 \mathrm{ft}$.

9204-35 NE (1)--Between Elkport and Garber, on County Road C7X bridge over Turkey River, on left upstream curb near bridge abutment and $1 \mathrm{ft}$ above bridge deck; chiseled square.

Elevation 670.29 ft.

9204-35 NE (2)--(REFERENCE POINT) Between Elkport and Garber, on County Road C7X bridge over Turkey River, on downstream curb between 20th and 21st guardrail posts from right end of bridge; chiseled arrow.

Elevation $670.40 \mathrm{ft}$.
9204-36 NW (1)--At Garber, on County Road C43 bridge over Turkey River, on center of left upstream guardrail; Iowa Highway Commission bench mark.

Elevation $672.10 \mathrm{ft}$.

9205-09 SW (1)--At Osborne, on State Highway 13 bridge over Volga River, on top of concrete guardrail at right downstream end of bridge; Iowa Highway Commission bench mark.

\section{Elevation $758.80 \mathrm{ft}$.}

9205-17 SE (1)--Approximately $1.2 \mathrm{mi}$ southwest of Osborne, on County Road C5X bridge over Cox Creek, on left downstream abutment curb and 2 in. above level of bridge deck; chiseled square.

Elevation $779.58 \mathrm{ft}$.

9205-22 SW (1)--At Mederville, on Evergreen Road bridge over Volga River, on top of retaining wall at right upstream end of bridge; chiseled square.

Elevation $755.86 \mathrm{ft}$.

9205-22 SW (2)--At Mederville, on Evergreen Road bridge over Volga River, on third guardrail stone post from right downstream end of bridge, on streamward side of post; chiseled square.

Elevation $759.26 \mathrm{ft}$.

9205-25 NE (1)--At Littleport, on County Road X21 bridge over Volga River, on left upstream wingwall curb; U.S. Geological Survey brass tablet stamped "15 JRE 1964 708."

Elevation $708.254 \mathrm{ft}$.

9205-25 NE (2)--(REFERENCE POINT) At Littleport, on County Road X21 bridge over Volga River, on top of upstream guardrail and left of 15 th guardrail post from right end of bridge; three filed marks.

Elevation $709.64 \mathrm{ft}$.

9206-10 NE (1)--At Volga, on County Road C2W bridge over Volga River, on top of right upstream wingpost; chiseled square.

Elevation $800.52 \mathrm{ft}$.

9206-10 NE (2)--(REFERENCE POINT) At Volga, on County Road C2W bridge over Volga River, on top of upstream guardrail and right of 22nd guardrail post from right end of bridge; two filed marks.

Elevation $800.59 \mathrm{ft}$.

9305-02 SE (1)--Approximately 2.3 mi south of Saint Olaf, on County Road X28 bridge over Roberts Creek, on right upstream end of bridge; Iowa Highway Commission bench mark.

Elevation $800.67 \mathrm{ft}$. 
9305-02 SE (2)--(REFERENCE POINT) Approximately 2.3 mi south of Saint Olaf, on County Road X28 bridge over Roberts Creek, on downstream guardrail and $80 \mathrm{ft}$ from right end of bridge; chiseled arrow.

Elevation $800.98 \mathrm{ft}$.

9305-13 SW (1)--Approximately 1.2 mi northeast of Elkader, on 250th Street bridge over Roberts Creek, on bridge deck at left downstream end of bridge; chiseled square.

Elevation $735.88 \mathrm{ft}$.

9305-13 SW (2)--(REFERENCE POINT) Approximately 1.2 mi northeast of Elkader, on 250th Street bridge over Roberts Creek, on downstream lip of bridge deck and $8.5 \mathrm{ft}$ from left end of bridge; chiseled arrow.

Elevation $735.87 \mathrm{ft}$.

9305-13 NW (1)--Approximately 1.5 mi northeast of Elkader, on State Highway 13 bridge over Roberts Creek, on left upstream wingwall; U.S. Geological Survey brass tablet stamped " 18 WEK 1964 reset 1979."

Elevation $770.212 \mathrm{ft}$.

9305-13 NW (2)--(REFERENCE POINT) Approximately 1.5 mi northeast of Elkader, on State Highway 13 bridge over Roberts Creek, on downstream guardrail and 90 feet from left end of bridge; chiseled arrow.

Elevation $769.35 \mathrm{ft}$.

9305-23 SW(1)--At Elkader, on Bridge Street bridge (Keystone Arch bridge) over Turkey River, on top of concrete guardrail at left upstream end of bridge; U.S. Geological Survey brass tablet stamped " 17 WEK 1964".

\section{Elevation $745.060 \mathrm{ft}$.}

9305-23 SW(2)--(REFERENCE POINT) At Elkader, on Bridge Street bridge (Keystone Arch bridge) over Turkey River, on edge of upstream concrete walkway between 8th and 9th guardrail posts from left end of bridge; chiseled arrow.

Elevation $740.59 \mathrm{ft}$.

9305-25 SE (1)--Approximately $1.6 \mathrm{mi}$ southeast of Elkader, on County Road ClX bridge over Roberts Creek, on left upstream wingwall; U.S. Geological Survey brass tablet stamped "33 WEK 1964".

Elevation $718.748 \mathrm{ft}$.

9305-25 SE (2)--(REFERENCE POINT) Approximately 1.6 mi southeast of Elkader, on County Road C1X bridge over Roberts Creek, on downstream guardrail at 7th guardrail post from right end of bridge; two filed marks.

Elevation $720.93 \mathrm{ft}$.
9305-26 NW (1)--Approximately $0.8 \mathrm{mi}$ south of Elkader, on State Highway 13 bridge over Turkey River, on top of concrete guardrail at right upstream end of bridge; Iowa Department of Transportation bench mark.

Elevation $732.88 \mathrm{ft}$.

9305-26 NW (2)--Approximately $0.8 \mathrm{mi}$ south of Elkader, on State Highway 13 bridge over Turkey River, on top of concrete guardrail at left upstream end of bridge; Iowa Department of Transportation bench mark.

Elevation $731.50 \mathrm{ft}$.

9305-26 NW (3)--(REFERENCE POINT) Approximately $0.8 \mathrm{mi}$ south of Elkader, on State Highway 13 bridge over Turkey River, on top of concrete guardrail at center of downstream side of bridge and $1 \mathrm{ft}$ right of wire weight; chiseled arrow.

Elevation $732.11 \mathrm{ft}$.

9405-25 SW (1)--At Saint Olaf, on County Road B65 bridge over Roberts Creek, on right downstream end of bridge; chiseled square.

Elevation $858.68 \mathrm{ft}$.

9405-25 SW (2)--(REFERENCE POINT) At Saint Olaf, on County Road B65 bridge over Roberts Creek, on downstream guardrail and $90 \mathrm{ft}$ from right end of bridge; chiseled arrow.

Elevation $859.90 \mathrm{ft}$.

9405-25 NW (1)--At Saint Olaf, on County Road X28 bridge over Roberts Creek, on left upstream end of bridge, on upstream rivet head; chiseled cross.

Elevation $854.88 \mathrm{ft}$.

9405-25 NW (2)--At Saint Olaf, on County Road X28 bridge over Roberts Creek, on right downstream wingwall; chiseled square.

Elevation $859.43 \mathrm{ft}$.

9405-36 SW (1)--Approximately $1.3 \mathrm{mi}$ south of Saint Olaf, on County Road X28 bridge over Roberts Creek, on downstream guardrail at left end of bridge; Iowa Highway Commission bench mark.

Elevation $827.53 \mathrm{ft}$

9405-36 SW (2)--(REFERENCE POINT) Approximately 1.3 mi south of Saint Olaf, on County Road X28 bridge over Roberts Creek, on downstream guardrail and 120 $\mathrm{ft}$ from left end of bridge; chiseled arrow.

Elevation $827.93 \mathrm{ft}$.

9405-36 NW (1)--Approximately $0.8 \mathrm{mi}$ south of Saint Olaf, on County Road X28 bridge over Roberts Creek, on upstream guardrail at right end of bridge; Iowa Highway Commission bench mark.

Elevation $840.33 \mathrm{ft}$. 
9405-36 NW (2)--(REFERENCE POINT) Approximately 0.8 mi south of Saint Olaf, on County Road X28 bridge over Roberts Creek, on downstream guardrail and $83 \mathrm{ft}$ from right end of bridge; chiseled arrow.

Elevation $842.79 \mathrm{ft}$.

9406-26 SW(1)--Approximately $5.5 \mathrm{mi}$ southeast of Elgin, on County Road W70 bridge over Turkey River, on upstream curb at left end of bridge; U.S. Geological Survey brass tablet stamped "45 WEK 1964".

Elevation $779.991 \mathrm{ft}$.

9406-26 SW(2)--Approximately $5.5 \mathrm{mi}$ southeast of Elgin, on County Road W70 bridge over Turkey River, on downstream curb at right end of bridge; chiseled square.

Elevation $779.94 \mathrm{ft}$.

9406-26 SW(3)--(REFERENCE POINT) Approximately $5.5 \mathrm{mi}$ southeast of Elgin, on County Road W70 bridge over Turkey River, on top of downstream guardrail between 10th and 11th guardrail posts from right end of bridge; chiseled arrow.

Elevation $782.59 \mathrm{ft}$.

9407-10 NE (1)--Approximately $1.5 \mathrm{mi}$ south of Clermont, on County Road W51 bridge over Turkey River, on top of old wingwall support at right downstream end of bridge; chiseled square.

Elevation $829.36 \mathrm{ft}$.

9407-10 NE (2)--Approximately $1.5 \mathrm{mi}$ south of Clermont, on County Road W51 bridge over Turkey River, on left downstream abutment curb and $0.5 \mathrm{ft}$ left of steel plate; chiseled square.

Elevation $829.78 \mathrm{ft}$.

9407-10 NE (3)--(REFERENCE POINT) Approximately $1.5 \mathrm{mi}$ south of Clermont, on County Road W51 bridge over Turkey River, on downstream curb between 10th and 11th guardrail posts from left end of bridge; chiseled arrow.

Elevation $829.99 \mathrm{ft}$.

9407-13 NW (1)--At Elgin, on County Road B64 bridge over Turkey River, on top of left downstream wingpost; chiseled square.

Elevation $815.56 \mathrm{ft}$.

9407-13 NW (2)--At Elgin, on County Road B64 bridge over Turkey River, on downstream curb at right end of bridge; chiseled square.
9407-13 NW (3)--(REFERENCE POINT) At Elgin, on County Road B64 bridge over Turkey River, on downstream curb between 20th and 21st cement guardrail posts from right end of bridge; chiseled arrow.

Elevation $814.29 \mathrm{ft}$.

9407-14 SE (1)--At Elgin, on County Road W55 bridge over Otter Creek, on upstream curb at left end of bridge; chiseled cross.

Elevation $809.62 \mathrm{ft}$.

9407-14 SE (2)--At Elgin, on County Road W55 bridge over Otter Creek, on left downstream end of bridge; chiseled square.

Elevation $809.77 \mathrm{ft}$.

9407-14 SE (3)--(REFERENCE POINT) At Elgin, on County Road W55 bridge over Otter Creek, on top of 10th guardrail post from left downstream end of bridge; three filed marks.

Elevation $816.07 \mathrm{ft}$.

9407-14 SW (1)--At Elgin, on County Road W51 bridge over Otter Creek, on top of right downstream wingpost; chiseled square.

Elevation $835.54 \mathrm{ft}$.

9407-14 SW (2)--(REFERENCE POINT) At Elgin, on County Road W51 bridge over Otter Creek, on top of downstream guardrail and right of 6 th guardrail post from left end of bridge; chiseled arrow.

Elevation $835.44 \mathrm{ft}$.

9407-29 NW (1)--Approximately 0.4 mi east of Brainard, on Dove Road bridge over Otter Creek, on left upstream wingwall; chiseled square.

Elevation $904.82 \mathrm{ft}$.

9407-29 NW (2)--(REFERENCE POINT) Approximately 0.4 mi east of Brainard, on Dove Road bridge over Otter Creek, top of downstream truss at center vertical support; chiseled arrow.

Elevation $908.71 \mathrm{ft}$.

9407-30 NE (1)--Approximately 0.5 mi west of Brainard, on Valley Road bridge over Otter Creek, on top of left downstream wingpost; chiseled square.

Elevation $925.71 \mathrm{ft}$.

9407-30 NE (2)--(REFERENCE POINT) Approximately $0.5 \mathrm{mi}$ west of Brainard, on Valley Road bridge over Otter Creek, on downstream guardrail between 4th and 5 th guardrail posts from left end of bridge; three chiseled marks. 
9507-29 SW(1)--Approximately $2.1 \mathrm{mi}$ northwest of Clermont, on County Road B40 bridge over Turkey River, on left downstream wingwall, chiseled cross.

Elevation $857.27 \mathrm{ft}$.

9507-29 SW(2)--(REFERENCE POINT) Approximately 2.1 mi northwest of Clermont, on County Road B40 bridge over Turkey River, on downstream curb between 14th and 15th guardrail posts from right end of bridge; chiseled square.

Elevation $859.98 \mathrm{ft}$.

9507-30 SE (1)--Approximately $2.7 \mathrm{mi}$ northwest of Clermont, on County Road B40 bridge over Turkey River, on center of downstream curb; chiseled square.

Elevation $862.68 \mathrm{ft}$.

9507-30 SE (2)--Approximately $2.7 \mathrm{mi}$ northwest of Clermont, on County Road B40 bridge over Turkey River, on corner of left upstream wingpost; chiseled square.

Elevation $865.02 \mathrm{ft}$.

9507-30 SE (3)--(REFERENCE POINT) Approximately 2.7 mi northwest of Clermont, on County Road B40 bridge over Turkey River, on downstream guardrail between 15th and 16th guardrail posts from right end of bridge; chiseled arrow.

\section{Elevation $864.06 \mathrm{ft}$.}

9507-34 SW (1)--At Clermont, on U.S. Highway 18 bridge over Turkey River, on right downstream end of bridge and approximately $5 \mathrm{ft}$ off of bridge on sidewalk, on ridge of manhole cover; chiseled cross.

\section{Elevation $846.73 \mathrm{ft}$}

9507-34 SW (2)--(REFERENCE POINT) At Clermont, on U.S. Highway 18 bridge over Turkey River, on downstream concrete guardrail, on right side of wire weight and approximately $10 \mathrm{ft}$ streamward of center pier; chiseled arrow.

Elevation 849.59 ft.

9508-08 SE (1)--Approximately 1.4 mi east of Eldorado, on County Road B40 bridge over Turkey River, on top of right downstream wingwall; chiseled square.

Elevation $920.20 \mathrm{ft}$.

9508-08 SE (2)--Approximately 1.4 mi east of Eldorado, on County Road B40 bridge over Turkey River, on top of right downstream wingwall; chiseled cross.

Elevation $922.99 \mathrm{ft}$
9508-08 SE (3)--(REFERENCE POINT) Approximately 1.4 mi east of Eldorado, on County Road B40 bridge over Turkey River, seven concrete guardrail sections from left downstream end of bridge; chiseled cross.

Elevation $922.46 \mathrm{ft}$.

9508-15 SE (1)--Approximately $3.5 \mathrm{mi}$ southeast of Eldorado on County Road B40 bridge over Turkey River, on top of concrete guardrail on left downstream end of bridge; chiseled square.

Elevation $902.81 \mathrm{ft}$.

9508-15 SE (2)--(REFERENCE POINT) Approximately 3.5 mi southeast of Eldorado on County Road B40 bridge over Turkey River, left of 10th concrete section from right downstream wingwall; chiseled square.

Elevation $907.31 \mathrm{ft}$.

9508-16 NE (1)--Approximately 2.5 mi east of Eldorado, on County Road W42 bridge over Turkey River, on left downstream wingwall at curb height; chiseled square.

Elevation $903.65 \mathrm{ft}$.

9508-16 NE (2)--Approximately 2.5 mi east of Eldorado, on County Road W42 bridge over Turkey River, on top of left upstream wingpost; chiseled square.

Elevation $906.07 \mathrm{ft}$.

9508-16 NE (3)--(REFERENCE POINT) Approximately 2.5 mi east of Eldorado, on County Road W42 bridge over Turkey River, on downstream curb between 12th and 13th guardrail posts from left end of bridge; chiseled arrow.

Elevation $903.92 \mathrm{ft}$.

9508-18 NW(1)--At Eldorado, on State Highway 150 bridge over Turkey River, on right upstream wingwall curb; Iowa Highway Commission bench mark.

Elevation $946.66 \mathrm{ft}$.

9508-18 NW(2)--At Eldorado, on State Highway 150 bridge over Turkey River, on left downstream abutment and 10 $\mathrm{ft}$ right of wingwall curb; chiseled square.

Elevation $938.16 \mathrm{ft}$.

9508-18 NW(3)--(REFERENCE POINT) At Eldorado, on State Highway 150 bridge over Turkey River, on 19th metal plate of old guardrail from right downstream end of bridge; three filed marks.

Elevation $940.93 \mathrm{ft}$.

9508-22 SE (1)--Approximately $4.0 \mathrm{mi}$ southeast of Eldorado, on Ironwood Road bridge over Turkey River, on left upstream curb of triple pony truss bridge; chiseled square.

Elevation $882.22 \mathrm{ft}$ 
9508-22 SE (2)--Approximately $4.0 \mathrm{mi}$ southeast of Eldorado, on Ironwood Road bridge over Turkey River, on top of left upstream wingpost of triple pony truss bridge; chiseled square.

Elevation $884.09 \mathrm{ft}$.

9508-22 SE (3)--(REFERENCE POINT) Approximately 4.0 mi southeast of Eldorado, on Ironwood Road bridge over Turkey River, on curb in center of middle pony truss of triple pony truss bridge; chiseled arrow.

Elevation $883.99 \mathrm{ft}$.

9508-25 NE (1)--Approximately 3.9 mi northwest of Clermont, on County Road B40 bridge over Turkey River, on left upstream wingpost; chiseled square.

Elevation $878.68 \mathrm{ft}$.

9508-25 NE (2)--(REFERENCE POINT) Approximately 3.9 mi northwest of Clermont on County Road B40 bridge over Turkey River, on top of downstream guardrail and 125 feet from left end of bridge; chiseled arrow.

Elevation $881.35 \mathrm{ft}$. 